\title{
Petrophysical and geochemical characteristics of late Variscan granites in the Karlovy Vary Massif (Czech Republic) - implications for gravity and magnetic interpretation at shallow depths
}

\author{
Vratislav BLECHA ${ }^{1, *}$, Miroslav ŠTEMPROK² \\ ${ }^{1}$ Institute of Hydrogeology, Engineering Geology and Applied Geophysics, Charles University, Albertov 6, 12843 Prague 2, Czech \\ Republic; vblecha@natur.cuni.cz \\ 2 Institute of Petrology and Structural Geology, Charles University, Albertov 6, 12843 Prague 2, Czech Republic \\ * Corresponding author
}

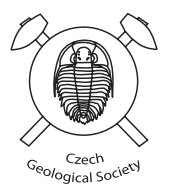

\begin{abstract}
The Karlovy Vary Massif (KVM) in northern Bohemia is a composite granite body built up of Late Variscan biotite, two-mica and lithium mica granites. We summarize the available whole-rock geochemical and petrological data and correlate them with similar information from three boreholes in the northern and southwestern parts of the Massif. The aim of the study was to determine whether various types of granites differ in their physical and chemical properties, and whether any differences in physical characteristics affect the accuracy of geophysical interpretation. In accord with the earlier studies, we distinguish two geochemically and petrophysically contrasting granite suites - the Older Intrusive Complex (OIC) and Younger Intrusive Complex (YIC). The geochemical data show that the OIC and YIC granites differ significantly in the content of most major-element oxides (like $\mathrm{SiO}_{2}, \mathrm{TiO}_{2}, \mathrm{FeO}, \mathrm{Fe}_{2} \mathrm{O}_{3 \text { tot }} \mathrm{MgO}$ and $\mathrm{CaO}$ ). As to physical parameters, the granites differ markedly in magnetic susceptibilities and in the contents of radioactive elements (U and Th). From gravity and magnetic data we compiled a $22 \mathrm{~km}$ long geophysical profile, which crosses two of the three studied boreholes. For the construction of geological model along this profile, we used the data on the petrophysical properties measured on samples from the boreholes. Densities of the individual granite types are very similar to each other and thus the distinction of the OIC and YIC granites based on gravity data is not possible. Magnetic susceptibility differs markedly for the OIC and YIC granites in the drill logs, but absolute values of magnetic susceptibilities are very low. Modelling showed that neither gravimetry nor magnetometry are suitable methods for distinguishing between the different types of granites. On the other hand, it proved that the spatial distribution of individual granite intrusions does not affect the overall interpretation of the shape, size and depth of the whole granite body.
\end{abstract}

Keywords: Variscan granites, Karlovy Vary Massif, petrophysical properties, geochemical composition, gravity and magnetic modelling Received: 20 January 2012; accepted: 4 June 2012; handling editor: V. Babuška

\section{Introduction}

A notable progress has been reached recently in the knowledge of granite magma generation, ascent and emplacement (Cruden 2006). It was suggested that much of the chemical variations within a granite body do not result from in situ differentiation but from a discontinuous accumulation of successive magma batches (Vigneresse 2007; Clemens et al. 2010). The Carboniferous to Early Permian magmatism in Central Europe produced large masses of igneous rocks during late stages of Variscan orogeny. The predominant rocks generated by partial melting and subsequent differentiation of felsic magmas in its Saxothuringian Zone are monzogranites and alkali feldspar granites of S-, I-, or A-type affinities (Förster and Romer 2010). The Saxothuringian granites are relatively well exposed in the NW part of the Bohemian Massif. Because of their association with ore deposits and thermal springs, many of them have been examined by drillings, surface and underground workings. The
Karlovy Vary Massif (KVM; Fig. 1), type locality of the Carlsbad twins, was studied since the early $19^{\text {th }}$ century and this research accumulated a wealth of data on various properties of its granites.

In the current paper we evaluate the petrophysical measurements on the granites from this region and correlate them with the available geochemical data. We use unpublished lithogeochemical data on the granites from the KVM (Lithogeochemical database of the Czech Geological Survey 2010) along with published or archive geochemical data from the Slavkovský les Mts. and hydrogeological studies in the vicinity of the Karlovy Vary spa. We also re-evaluate geochemical data from the structural drill hole in Krásno (Fig. 2).

The majority of geochemical and petrophysical data come from rock samples of structural drill holes HJ-1, HJ-2 and K-25. The obtained density and magnetic parameters were used for the construction of a geophysical model along a $22 \mathrm{~km}$ long profile across drill holes HJ-1 and HJ-2. We modelled the gravity and magnetic data 


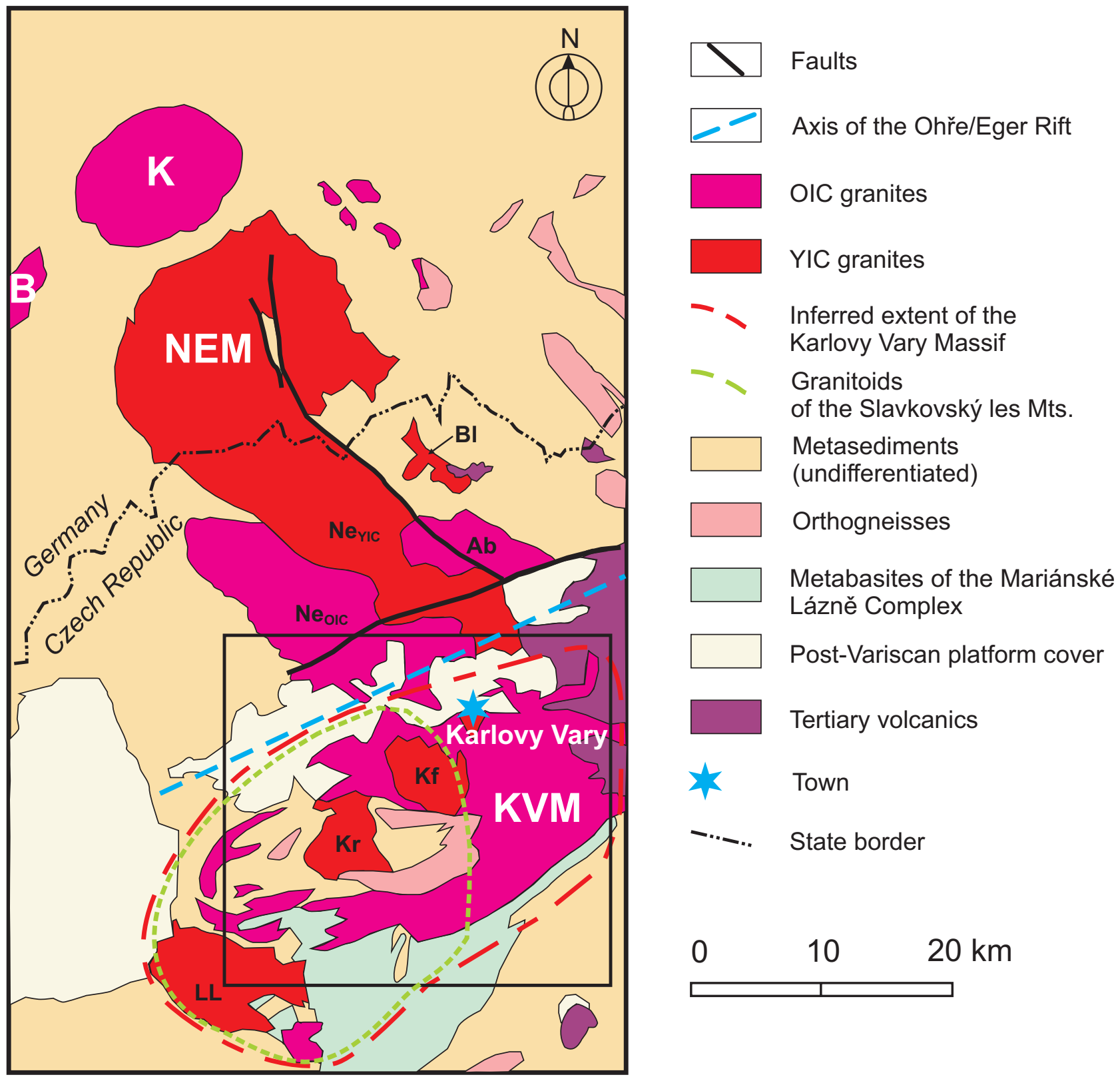

Fig. 1 Position of the Western Pluton of the Krušné hory/Erzgebirge granite Batholith. KVM - Karlovy Vary Massif, NEM - Nejdek-Eibenstock Massif, K - Kirchberg Massif, B - Bergen Massif, B1 - Horní Blatná Massif, Ab - Abertamy granites, $\mathrm{Ne}_{\mathrm{YIC}}-\mathrm{Nejdek}_{\mathrm{YIC}}$ granites, Ne $\mathrm{OIC}-\mathrm{Nejdek}$ OIC granites, $\mathrm{Kf}$ - Kfely granites, $\mathrm{Kr}$ - Krudum Massif, LL - Lesný-Lysina (Kynžvart) Massif (modified from Hejtman 1984 and Cháb et al. 2007). Black rectangle marks the area of Fig. 2.

simultaneously so that the resulting geological section corresponds to the both physical fields. This approach reduces the ambiguity in interpretation and shows hidden parts of mafic Tertiary volcanic rocks.

\section{Geological setting}

Geological structure of western Bohemia represents a junction of the Moldanubian, Saxothuringian and Tep-
lá-Barrandian zones of the Central European Variscan system which differ in metamorphic grade, deformation style and nature of the underlying lithospheric mantle domains (Franke 1989; Babuška and Plomerová 2001,

Fig. 2 Geological sketch of the KVM based on geological maps by Kvičinský (1989), Zoubek (1996), Schovánek (1997) and Cháb et al. (2007). OIC - Older Intrusive Complex granites, YIC - Younger Intrusive Complex granites. The YIC granite distribution is modified by the present study. 


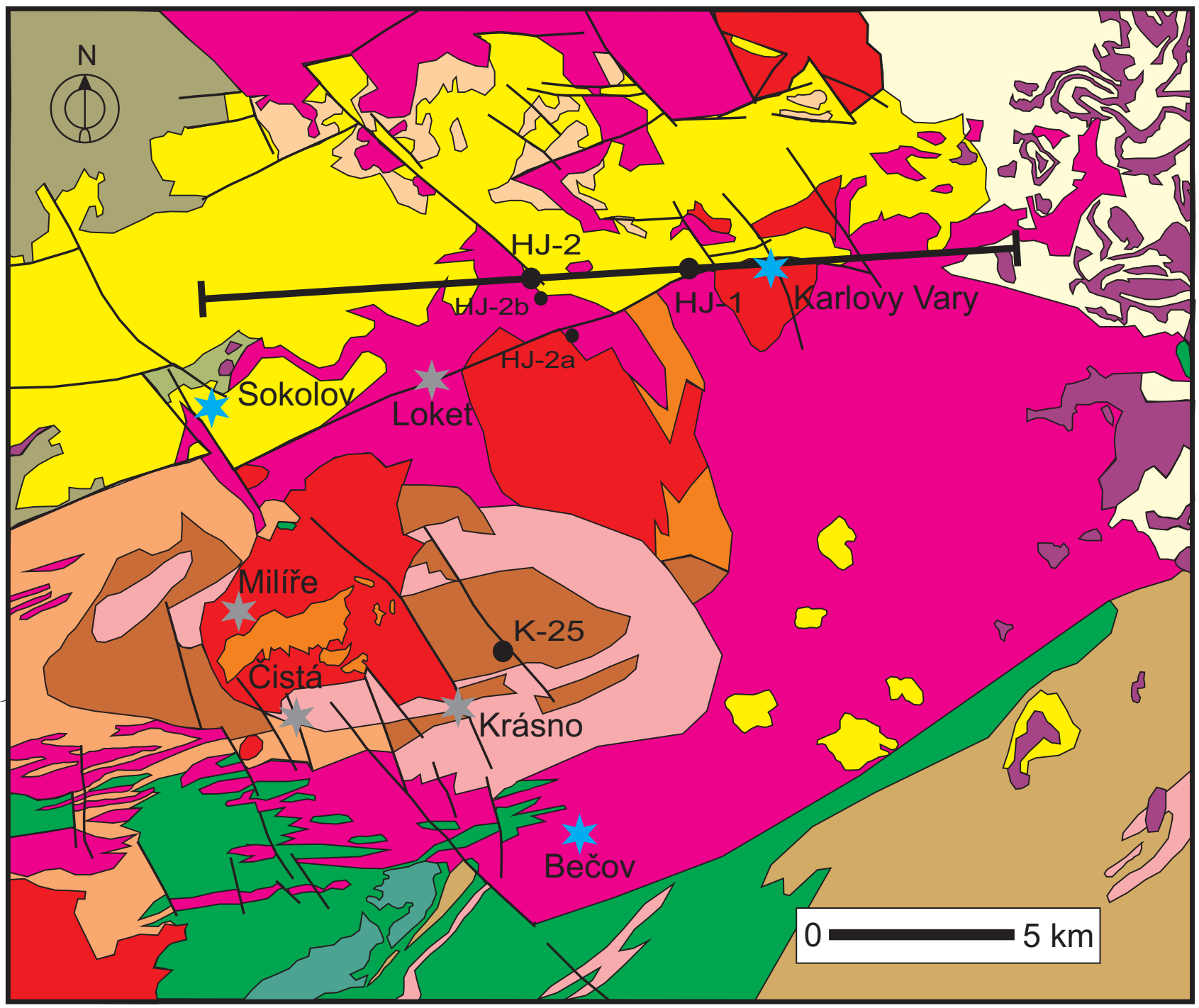

$\square$ serpentinite

$\square$ amphibolite

$\square$ orthogneiss

migmatitic gneiss

gneiss

with amphibolite

mica schist

phyllite

$\square$ hornfels

major faults

is towns $\square$ OIC granite

$\square$ YIC microgranite (granite porphyry)

$\square$ YIC granite

kaolinized granite

Tertiary volcanics

Tertiary tuffs

Tertiary sediments

drill holes

geophysical profile

it villages 
2010; Babuška et al. 2007). Late Variscan granites form nearly thirty percent of the crystalline basement (Trzebski et al. 1997) in the NW part of the Bohemian Massif. They cause marked negative gravity anomalies in the crystalline complex, with the Krušné hory/Erzgebirge anomaly being the most significant (Ibrmajer and Suk 1989; Sedlák et al. 2009).

The Krušné hory/Erzgebirge Batholith $\left(\sim 6000 \mathrm{~km}^{2}\right)$ consists of three plutons, the Western, Middle and Eastern (Hejtman 1984), even though some authors treated it as a single entity (e.g. Škvor 1986). The outcrops of the Western Pluton $\left(\sim 1000 \mathrm{~km}^{2}\right.$, Fig. 1) are separated into the Nejdek-Eibenstock Massif (NEM), north of the NE-SW trending Eger/Ohře Rift zone and the KVM in the south and southwest, which includes also the Slavkovský les Mts. granitoids (Fig. 1). The latter body is approximately parallel with the Ohře/Eger Rift and has the aspect ratio of 0.35 . The KVM intruded the boundary between the Saxothuringian and Moldanubian zones. It has intrusive, sharp contact with the crystalline country rocks; in the south-west and west, the strong contact metamorphism caused the origin of sillimanite-cordierite hornfelses (Fiala 1968). Based on interpretation of gravity data, Blecha et al. (2009) concluded that the body of the Lesný-Lysina Massif represents a separate intrusion, which is only $3-4 \mathrm{~km}$ thick but merges with the main body of the KVM at depth.

The Sokolov Basin between the NEM and KVM is filled by Paleogene and Neogene sediments with coal seams; in the east it is penetrated and partly covered by lavas and tuffs of the Doupov stratovolcano. The granites are cut by rare lamprophyre dikes (Štemprok et al. 2008b) and by small bodies of Tertiary volcanics.

The petrology and geochemistry of granitoids in the KVM was studied by Neužil and Konta (1965), Zoubek (1951, 1963, 1966), Palivcová et al. (1968), Fiala (1968), Štochl (1969), Vylita (1987, 1990), Vylita et al. (1991), Štemprok et al. (1996) and Kováŕíková et al. (2010). Heavy mineral concentrates from the main granite types were examined by Kodymová and Štemprok (1993) and trioctahedral micas by Minařík et al. (1984) with Štemprok et al. (1996).

Western Pluton consists of a succession of granites, which form a coherent body apparently identical in all the outcrops (see review by Hejtman 1984). Low-F biotite and low-F two-mica granites, as well as high-F, high- $\mathrm{P}_{2} \mathrm{O}_{5}$ lithium mica granites distinguished by geochemical work in the Erzgebirge (Förster et al. 1999), can be well grouped into two major intrusive complexes which differ in age, petrology and chemistry. The first suite of biotite monzogranites termed the Older Intrusive Complex (OIC) (Lange et al. 1972; Štemprok 1986) includes subordinate early dioritic intrusions (Fiala 1968; Kováŕíková et al. 2007, 2010). The second, the Younger
Intrusive Complex (YIC), comprises monzogranites and syenogranites ranging to alkali feldspar granites. Similar two major granite intrusive complexes were distinguished in the Fichtelgebirge/Smrčiny Pluton by Hecht et al. (1997). Porphyritic microgranites, the earliest intrusions of the YIC in the KVM, show rarely two-phase textures (Štemprok et al. 2008a). The granites in the southern NEM are divided into the Nejdek and Abertamy OIC granites, Nejdek YIC granites and granites of the Blatná Massif (Absolonová and Matoulek 1975). The KVM is composed of the OIC biotite granites (partly of the Loket type), of the Kfely two-mica granites, porphyritic microgranites and two-mica medium- or coarse-grained YIC granites (Fig. 1).

The most voluminous masses of igneous rocks originated in the Saxothuringian Zone in the interval of (340) 335-320 Ma (Förster and Romer 2010). The radiometric data for the Erzgebirge granites indicate an intrusion interval of c. 325-318 Ma (Förster et al. 1999). The OIC granite from southern part of the NEM was dated at $322.8 \pm 3.5 \mathrm{Ma}$ by $\mathrm{Pb}-\mathrm{Pb}$ zircon evaporation method (Kováríková et al. 2007). However, dating of the YIC granites in the Slavkovský les Mts. failed because of the high common lead contents in zircon crystals (Kováŕíková et al. 2010).

The KVM is in the west at contact with migmatitized paragneisses, migmatites and orthogneisses of the Slavkovský les Mts. (Fiala 1968) accompanied by paragneisses and sillimanite-cordierite hornfelses. In the south occur mafic rocks of the Mariánské Lázně Complex represented by serpentinites, amphibolites and eclogites (Jelínek et al. 1997), while in the southeast, the OIC granites cut paragneisses with amphibolite intercalations (Fig. 2). Blecha et al. (2009) suggested that the KVM is a tabular body about $10 \mathrm{~km}$ thick with a presumed feeding channel along its eastern boundary. Its growth occurred possibly by repeated additions of tabular or sheet-like magmatic pulses. The authors also showed that the Lesný-Lysina granite Massif is a separate body, which merges with the KVM at depth, but has a feeding channel different from the KVM.

The hydrogeological drill holes HJ-1 (511 m deep) and HJ-2 (1200 m deep) west of Karlovy Vary were designed to identify tectonic zones conducting thermal springs (Vylita 1987, 1990). Domečka (in Vylita 1987 and 1990) assigned the granites intersected by both drill holes to the OIC. He identified the lower HJ-2 granites as the "Nejdek type". We revisit this interpretation in the northern KVM and propose that the upper granites belong to the OIC, and the lower granites to the YIC, as they have intruded later and crop out in a number of places of the Western Pluton (Fig. 1). Numerous shallower drill holes carried out in the Karlovy Vary town area were interpreted by Vylita et al. (1991). They show the effects of thermal 
springs on granite composition, leading to feldspars decomposition and a considerable $\mathrm{Na}_{2} \mathrm{O}$ loss.

The drill hole KV-25 (800 m deep) at Krásno (Jarchovský 1994) is located in the crystalline envelope of the Krudum Massif. It intersected the YIC granites high in albite in a Li-rich variety and shows the deep structure of its highly evolved members. The Krudum Massif is specialized in tin and tungsten mineralization. It shows a notable geochemical and textural difference compared to other YIC granites observed in the drill holes near Karlovy Vary or in the NEM (Klomínský 1965; Vylita et al. 1991). In accord with Fiala (1968), we treat it as a separate body and re-evaluate some unpublished geochemical data for this drill hole resulting from an exploration program of the Czech Geological Survey in 1970.

\section{Petrology of granites in the KVM}

The outcrops of the OIC granites in the KVM show a horseshoe shape encircling the crystalline core of the Slavkovský les Mts. (Fig. 2). The main variety is relatively homogeneous, medium- to coarse-grained biotite monzogranite with K-feldspar phenocrysts (10-30 vol. \%) up to $10 \mathrm{~cm}$ in size, containing quartz, plagioclase $\left(\mathrm{An}_{07-28}\right)$, K-feldspar, biotite (5-15 vol. \%) and muscovite ( 0.5 to 3.5 vol. \%) in the groundmass. Pivec (1973) identified K-feldspar phenocrysts as orthoclase perthites with a low triclinity; common is Carlsbad twinning (type locality). Accessories are apatite, zircon, ilmenite, rutile, garnet, amphibole and augite (Kodymová and Štemprok 1993). Xenoliths are rare but where present they are of dioritic composition with leucocratic margins. They exhibit composition close to the redwitzites, forming minor bodies in the Slavkovský les Mts. (Kováŕíková et al. 2010).

In the Slavkovský les Mts., the OIC granites occur predominantly in the Loket facies (Štochl 1969; Breiter et al. 1991), whose groundmass is of granodioritic composition. Rare (sub-) horizontal aplite dikes with sharp contacts cut the OIC granites. They are equigranular with grain size 0.5 to $1 \mathrm{~mm}$, consisting of quartz, plagioclase $\left(\mathrm{An}_{0-14}\right), \mathrm{K}$-feldspar, biotite and muscovite. Biotite flakes are frequently bleached; muscovite is coarsely tabular to skeletal. Accessories include rutile, zircon, leucoxene, garnet, anatase, apatite, andalusite, topaz and tourmaline.

Two-mica granites are very common in the KVM. The YIC granites in the Karlovy Vary town area are variously textured muscovite-biotite granites, which occasionally pass into each other over short distances (Zoubek 1963; Vylita et al. 1991; Štemprok et al. 1996). The fine-grained granites are either equigranular or porphyritic. The groundmass grain size varies between 0.3 and $1.5 \mathrm{~mm}$, plagioclase composition is $\mathrm{An}_{7-19}$, biotites are close to annite. Accessories include zircon, apatite, ilmenite, garnet, augite, amphibole, rutile, titanite, topaz and actinolite (Kodymová and Štemprok 1993). Kfely granite occurs in three varieties: marginal fine-grained, predominant medium-grained with sparse phenocrysts and leucocratic (aplitic). It was thought to have a higher vertical position in relation to the enclosing OIC granites (Zoubek 1963).

The microgranites considered as the earliest among the YIC granites (Zoubek 1963) form a composite NW striking dike $c .10 \mathrm{~km}$ in length interrupted on the surface by the body of Kfely granite (Fig. 1). The porphyritic microgranite occasionally exhibits two-phase textures (Štemprok et al. 2008a).

The Krudum Massif is a complex body of the YIC granites of roughly $7 \times 7.5 \mathrm{~km}$ outcrop size in the NW part of the KVM (Fig. 1). It consists of the fine-grained porphyritic biotite granite with muscovite (Fig. 2), resembling porphyritic microgranites in the KVM, two-mica Milíre granite and lithium-mica (lithionitetopaz) Čistá and Krásno granites (Fiala 1968). At its southeastern margin near Krásno greisen deposits occur (Jarchovský 2006). The drill hole K-25 penetrated into lithium mica granites under the paragneiss (migmatite) envelope and traversed greisens and greisenized granites below the contact.

\section{Petrology of the drill holes}

The drill hole HJ-1, which reached a depth of $511 \mathrm{~m}$, was located at the southern border of the Sokolov Basin near the outcrop of the OIC granites. Domečka in Vylita (1987) described the granites from the borehole as porphyritic or equigranular biotite granites of the OIC, which at a depth of $465 \mathrm{~m}$ passed into fine- to mediumgrained two-mica granites. In the upper granites, biotite (5.6-9.9 vol. \%) is the only femic mineral. Muscovite is subordinate and occurs as secondary intergrowths or laths rimming biotite flakes or as separate sericite aggregates. The lower two-mica granites contain 1-2 vol. \% of biotite and $6.5-8.3$ vol. \% of muscovite. Zones with dominant biotite or muscovite alternate. The granites of both complexes are intersected by mylonites and cataclasites (of several meters to a hundred of meters thickness) accompanied by silicification. Both suites are intruded by dikes of fine-grained leucogranites ranging to aplites and pegmatites. The latter form rare bodies up to several $\mathrm{dm}$ across containing tourmaline.

The drill hole HJ-2, also located at the southern border of the Sokolov Basin, reached a depth of $1200 \mathrm{~m}$. In its vicinity two shallow boreholes (HJ-2a and $\mathrm{HJ}-2 \mathrm{~b}$ ) were drilled, both to a depth of $150 \mathrm{~m}$ (Vylita 1987). The drill hole HJ-2a was located in a close vicinity of 
the Kfely granite outcrop (Fig. 2). The drill hole HJ-2 penetrated from 45 to $46.8 \mathrm{~m}$ Upper Oligocene volcanic tuffites and tuffitic clays, to $66.2 \mathrm{~m}$ it revealed clays and claystones with the Josef coal seam $(58.7-63.1 \mathrm{~m})$ and another nameless thin coal seam $(66.0-66.2 \mathrm{~m})$. The basal Lower Oligocene sandstones show normal grading with layers of quartz conglomerates to a depth of 72.7 $\mathrm{m}$. Below them strongly altered granites were traversed to a depth of $81.5 \mathrm{~m}$. Between 81.5 and $406.5 \mathrm{~m}$, the drill hole intersected porphyritic biotite granites classified by Domečka in Vylita (1990) as the Loket type (OIC). Under $198 \mathrm{~m}$ they enclose enclaves of granodiorite-tonalite, which formed from 201 to $232.2 \mathrm{~m}$ a larger continuous body. Enclaves contain c. 35 vol. \% of each quartz and plagioclase and 24 vol. \% of biotite. At 403.9 to $436.0 \mathrm{~m}$ the granites are strongly crushed, with incipient breccia textures. Angular fragments are frequently cemented by a silica-rich matrix. The granites of the Loket type were intruded by numerous dykes of biotite or muscovite leucogranites and aplites, of mostly dm scales to a maximum thickness of $5 \mathrm{~m}$, some compositionally close to the YIC granites (Tab. 2). The main tectonic zones are in the intervals 262.5-312.1 and 317.0-371.4 $\mathrm{m}$. At 436.0 to $469.7 \mathrm{~m}$ occur cataclastic and hydrothermally altered granites. The interval from 469.7 to 571.3 $\mathrm{m}$ is formed by altered medium- to coarse-grained twomica granites with diffusely bordered layer of fine- to medium-grained granites $(485-513 \mathrm{~m})$ in places intersected by quartz veinlets.

The lower part of the profile from $571.3 \mathrm{~m}$ consists of medium- to coarse-grained two-mica granite with mostly serial or scarcely porphyritic texture. This granite contains from 586.2 to $594.0 \mathrm{~m}$ and from 620.3 to $635.0 \mathrm{~m}$ layers of fine- to medium-grained two-mica porphyritic granites passing to the predominant granite. The twomica granites contain biotite (3-7 vol. \%) and muscovite (3-10 vol. \%). There were observed no systematic changes in the volume percentages of quartz, plagioclase and K-feldspar with the depth (Vylita 1990). The amount of biotite in the upper granites varies between 5.2 and 17.5 vol. \%, the sample from the depth of $250 \mathrm{~m}$ corresponds to a dioritic enclave rich in biotite, with low K-feldspar, high plagioclase and moderate quartz modal contents. The increased amount of muscovite (up to 10.3 vol. \%) is typical of the lower granites.

Both drillings were systematically sampled for chemical analyses in interval of $c .100 \mathrm{~m}$. For HJ-1, the chemical analyses were carried out in the laboratory of the Czech Geological Survey in Prague (Vylita 1987). $\mathrm{FeO}$ and $\mathrm{Fe}_{2} \mathrm{O}_{3}$ were measured separately (Tab. 1). The samples of the drill core of HJ-2 were analysed for majorelement oxides and some for selected trace elements (As, $\mathrm{Cd}, \mathrm{Cu}, \mathrm{Mo}, \mathrm{Nb}, \mathrm{Pb}, \mathrm{Rb}, \mathrm{Sn}, \mathrm{Sr}, \mathrm{U}, \mathrm{V}, \mathrm{Y}, \mathrm{Zn}$ and $\mathrm{Zr}$ ) in the chemical laboratory of Geoindustria in Prague-Černošice by XRF (Vylita 1990). The iron content was determined as $\mathrm{Fe}_{2} \mathrm{O}_{3}$ tot (Tab. 2).

The drill hole K-25 near Krásno in the Slavkovský les Mts., which was $800 \mathrm{~m}$ deep, traversed migmatitized paragneisses to a depth of $230 \mathrm{~m}$ and passed into albite and leucocratic granite with small bodies of fine-grained porphyritic granite, and from about $450 \mathrm{~m}$ downwards it traversed Li-mica granite. The paragneisses carried dikes of diorites and quartz diorites (up to $80 \mathrm{~m}$ thick) and of medium-grained to aplitic granites. Greisens originated in the contact zone of the granites (Jarchovský 1994). The drill core from $70 \mathrm{~m}$ to a depth of 658 $\mathrm{m}$ was analysed in $1 \mathrm{~m}$ segments for $\mathrm{Na}_{2} \mathrm{O}, \mathrm{K}_{2} \mathrm{O}, \mathrm{Li}_{2} \mathrm{O}$, $\mathrm{F}, \mathrm{Sn}, \mathrm{W}, \mathrm{Rb}$, and $\mathrm{Cs}$ in the laboratory of the Czech Geological Survey in Prague.

\section{Geophysical data}

For the geophysical analysis, we extracted gravity and magnetic data from the grid of $0.25 \times 0.25 \mathrm{~km}$ provided by the Czech Geological Survey - Geofond (Čápová et al. 2004).

Gravity data are Bouguer anomalies calculated for reduction density of $2670 \mathrm{~kg} / \mathrm{m}^{3}$. Theoretical values of gravity were computed from the World Geodetic System 1984 (WGS 84) gravity formula and the terrain corrections were applied to $166.7 \mathrm{~km}$ distance from measured stations. Original gravity data in the area of study are derived from the gravity mapping on the scale of $1: 25000$. Average spacing of gravity stations was 5 stations per $\mathrm{km}^{2}$ and mean square error of measurements did not exceed $0.05 \mathrm{mGal}$.

Magnetic data are anomalies $\Delta \mathrm{T}$. Anomaly $\Delta \mathrm{T}$ is the scalar difference between the value of total vector of the geomagnetic field $\mathrm{T}$ and the normal geomagnetic field $\mathrm{T}_{\mathrm{n}}$ in the area of study. Normal field $T_{n}$ is the International Geomagnetic Reference Field (IGRF) related to epoch 1981. Values of total geomagnetic vector $\mathrm{T}$ were measured by airborne survey with the flight lines at a constant ground clearance of $80 \mathrm{~m}$. The distance between parallel flight lines was $250 \mathrm{~m}$, distance between orthogonal cross-tie lines $3500 \mathrm{~m}$. Mean square error of measurements did not exceed $3 \mathrm{nT}$.

We used GM-SYS program for profile modelling of gravity and magnetic data (GM-SYS Modelling 2012). In this program, the geological units are visualized as tabular prisms with axes in their strike direction. These prisms may be truncated along the strike at some distance. Beyond the ends of the prisms there are new prisms of the same cross section, but with different densities. The two ends of the prisms may be asymmetrically positioned relative to the line of profile or, if needed, both may be on the same side of the profile plane. This concept is 


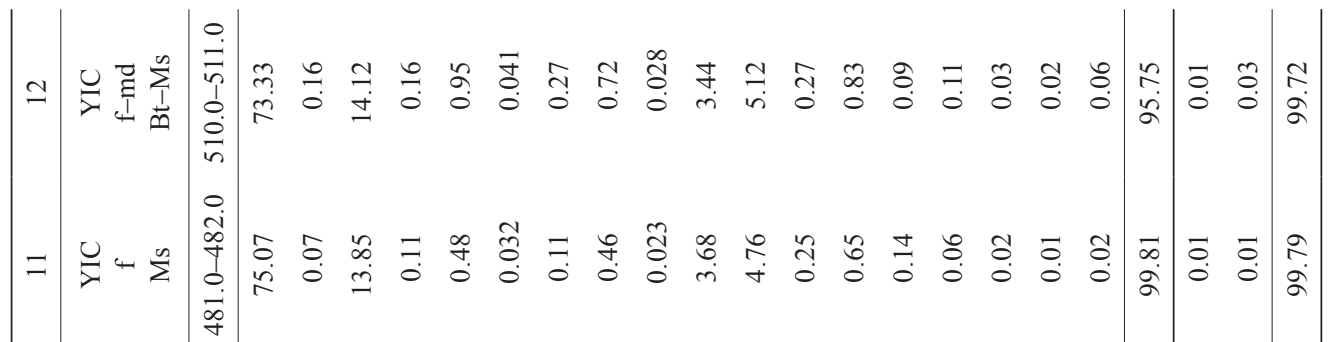

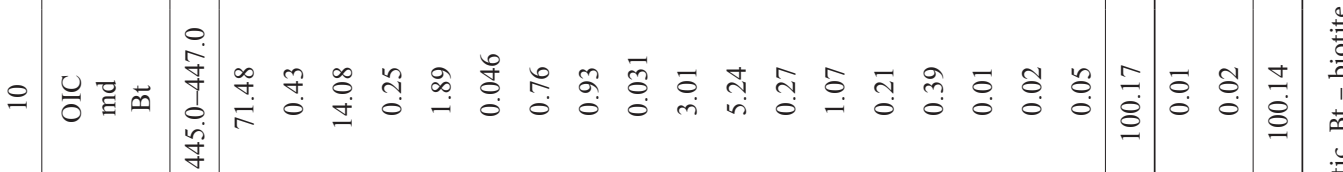

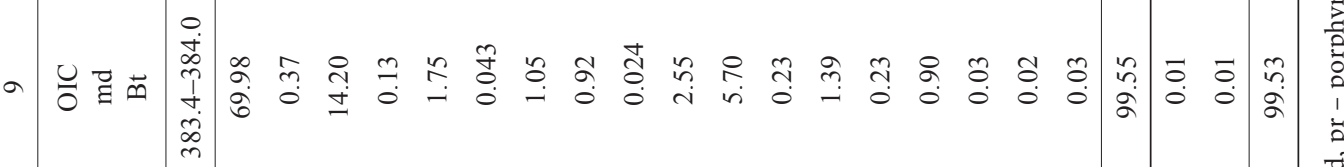

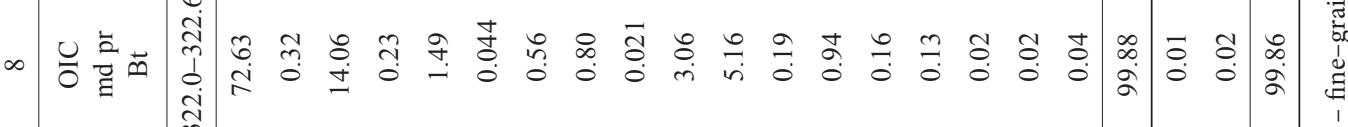

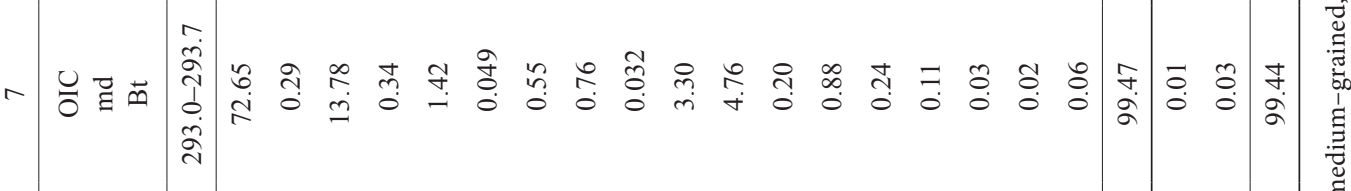

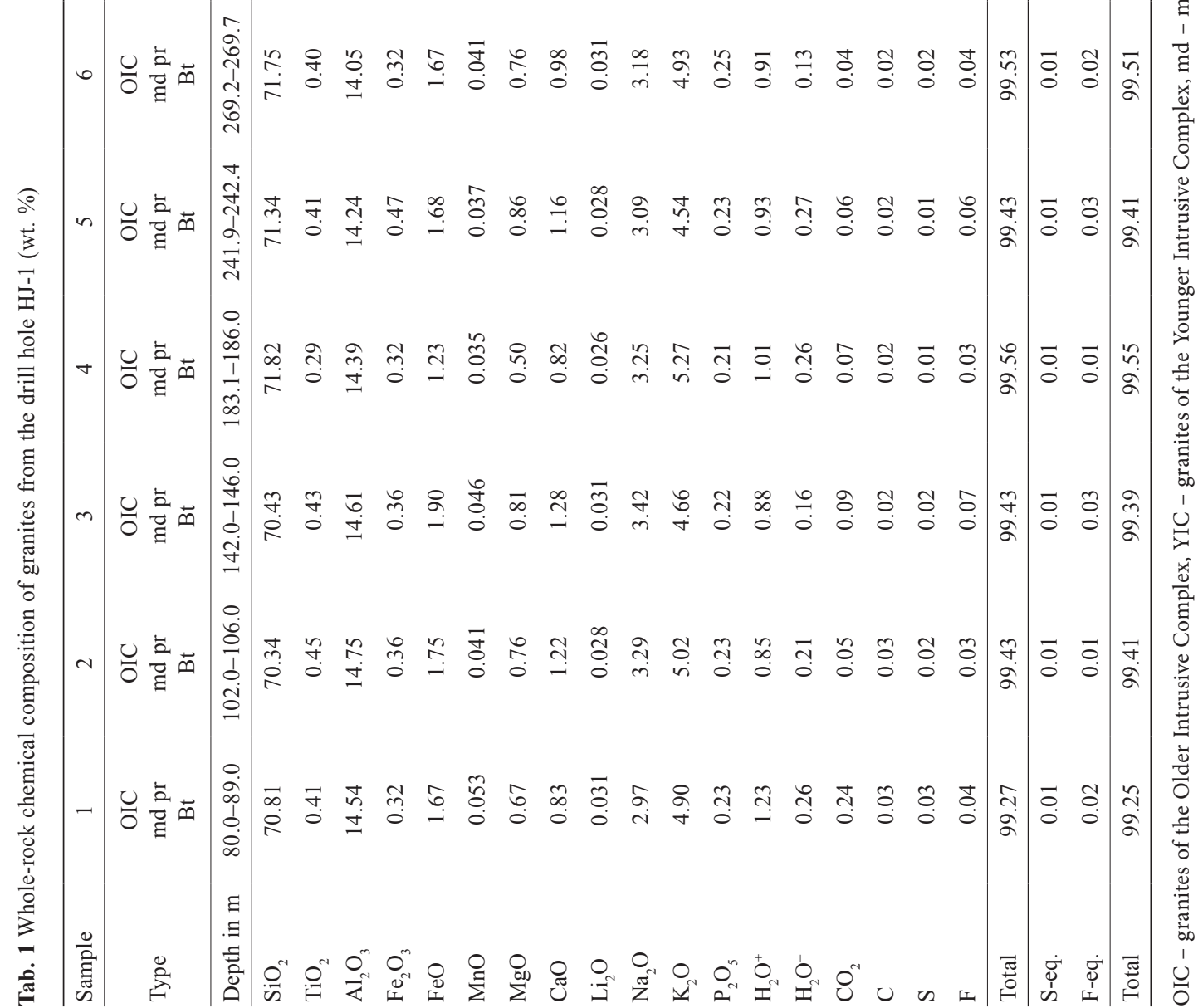


Tab. 2 Whole-rock chemical composition of granites from the drill hole HJ-2

\begin{tabular}{|c|c|c|c|c|c|c|c|c|}
\hline Sample & 1 & 2 & 3 & 4 & 5 & 6 & 7 & 8 \\
\hline Type & $\begin{array}{c}\text { OIC } \\
\text { md-cs } \\
\text { pf Bt }\end{array}$ & $\begin{array}{c}\text { OIC } \\
\text { md-cs } \\
\text { pr Bt }\end{array}$ & $\begin{array}{c}\text { YIC } \\
\text { cs pr } \\
\text { Bt }\end{array}$ & $\begin{array}{c}\text { OIC } \\
\text { fn pr } \\
\text { Bt gnd }\end{array}$ & $\begin{array}{l}\text { OIC } \\
\text { alt } \\
\text { myl }\end{array}$ & $\begin{array}{c}\text { OIC } \\
\text { alt } \\
\text { myl }\end{array}$ & $\begin{array}{c}\mathrm{OIC} \\
\mathrm{md}-\mathrm{cs} \\
\mathrm{Bt}\end{array}$ & $\begin{array}{c}\text { YIC } \\
\text { fn-md pr } \\
\text { Ms-Bt }\end{array}$ \\
\hline Depth in $\mathrm{m}$ & $114.5-115.0$ & $153.0-154.0$ & $170.5-171.0$ & $216.0-216.5$ & $279.0-280.0$ & $301.0-302.0$ & $373.0-374.0$ & $494.5-495.0$ \\
\hline $\mathrm{SiO}_{2}$ & 66.62 & 65.90 & 73.22 & 66.28 & & & 66.86 & 77.33 \\
\hline $\mathrm{TiO}_{2}$ & 0.63 & 0.67 & 0.28 & 0.69 & & & 0.61 & 0.15 \\
\hline $\mathrm{Al}_{2} \mathrm{O}_{3}$ & 15.89 & 16.64 & 14.26 & 15.48 & & & 15.51 & 12.58 \\
\hline $\mathrm{Fe}_{2} \mathrm{O}_{3 \text { tot }}$ & 3.99 & 3.60 & 1.63 & 4.69 & & & 3.92 & 0.98 \\
\hline $\mathrm{MnO}$ & 0.085 & 0.081 & 0.055 & 0.095 & & & 0.096 & 0.045 \\
\hline $\mathrm{MgO}$ & 1.10 & 1.12 & 0.31 & 1.84 & & & 1.36 & 0.27 \\
\hline $\mathrm{CaO}$ & 1.98 & 1.90 & 1.44 & 1.50 & & & 1.47 & 0.80 \\
\hline $\mathrm{Na}_{2} \mathrm{O}$ & 2.91 & 3.10 & 3.12 & 1.98 & & & 2.32 & 0.10 \\
\hline $\mathrm{K}_{2} \mathrm{O}$ & 4.46 & 5.06 & 3.96 & 4.17 & & & 4.69 & 5.03 \\
\hline $\mathrm{P}_{2} \mathrm{O}_{5}$ & 0.34 & 0.34 & 0.14 & 0.24 & & & 0.35 & 0.23 \\
\hline LOD & 0.58 & 0.51 & 0.40 & 1.12 & & & 1.03 & 0.43 \\
\hline LOI & 1.72 & 1.31 & 1.30 & 2.76 & & & 2.56 & 2.63 \\
\hline Total & 100.31 & 100.23 & 100.12 & 100.85 & & & 100.78 & 100.58 \\
\hline As & & $<5$ & & 9 & 33 & 65 & & 13 \\
\hline $\mathrm{Cu}$ & & $<5$ & & 12 & $<5$ & 8 & & $<5$ \\
\hline $\mathrm{Nb}$ & & 23 & & 19 & 15 & 15 & & 19 \\
\hline $\mathrm{Pb}$ & & 40 & & 31 & 21 & $<10$ & & 24 \\
\hline $\mathrm{Rb}$ & & 169 & & 165 & 307 & 157 & & 322 \\
\hline $\mathrm{Sn}$ & & $<10$ & & $<10$ & $<10$ & 23 & & 13 \\
\hline $\mathrm{Sr}$ & & 297 & & 180 & 122 & 108 & & 71 \\
\hline V & & 38 & & 56 & 29 & 28 & & $<20$ \\
\hline $\mathrm{Y}$ & & 30 & & 30 & 27 & 22 & & 29 \\
\hline
\end{tabular}

Upper part in wt. \%, lower part in ppm. In all the samples analysed for trace elements are the values of $\mathrm{Mo}<10, \mathrm{U}<15$ and Cd $<15$ ppm. OIC - granites of the Older Intrusive Complex, YIC - granites of the Younger Intrusive Complex, gdn - granodiorite of the OIC, cs - coarse-grained, md - medium-grained, fn - fine-grained, pr - porphyritic, Bt - biotite, Ms - muscovite, alt - hydrothermally altered, myl - mylonitized, LOD loss on drying, LOI - loss on ignition.

termed 2.75D modelling. GM-SYS modelling program takes into account that the gravity data were obtained by ground measurements, whereas the magnetic data come from airborne survey at $80 \mathrm{~m}$ above the ground.

\section{Vertical changes in petrophysical properties and chemical compositions}

Petrophysical properties and chemical compositions of rock samples from boreholes are in the Figs 3-4 (borehole HJ-1), 5-6 (borehole HJ-2) and 7-8 (borehole K-25). Data for construction of petrophysical graphs are in the manuscripts by Vaněčková (1988) - HJ-1, Dolanská (1989) - HJ-2 and Čápová et al. (2004) - K-25. Geochemical data come from Vylita $(1987,1990)$ for HJ-1 and HJ-2 and from unpublished analytical file for K-25 boreholes.

For the boreholes HJ-1 and HJ-2, density parameters (porosity, dry bulk density, grain density), magnetic parameters (susceptibility, Q-ratio) and radiometric pa- rameters (gamma-ray activity, contents of $\mathrm{U}$, Th and $\mathrm{K}$ ) are presented. Königsberger ratio Q expresses relative importance of the remanent $\left(\mathrm{M}_{\mathrm{r}}\right)$ and induced $\left(\mathrm{M}_{\mathrm{i}}\right)$ parts of magnetization $\left(\mathrm{Q}=\mathrm{M}_{\mathrm{r}} / \mathrm{M}_{\mathrm{i}}\right)$. In borehole $\mathrm{K}-25$, magnetic susceptibility was recorded only to a depth of 630 $\mathrm{m}$. Remanent magnetization was not measured, thus the values of the Q-ratio are unknown.

Density parameters were acquired by the "triple weighing" method. A rock sample was dried up to $105^{\circ} \mathrm{C}$ to constant mass $\left(M_{1}\right)$. After that it was inserted into a desiccator and vacuumed. In the desiccator, the sample was impregnated with distilled water. Impregnated samples were weighted in distilled water $\left(M_{2}\right)$ and then in the air $\left(M_{3}\right)$. From these three weighings, it was possible to calculate grain density, dry bulk density and porosity. Magnetic susceptibility was measured by kappabridge KLY-2, remanent magnetization (for calculation of Königsberger ratio Q) by spinner magnetometer JR-4. Gamma-ray activity and contents of radioactive elements $\mathrm{Th}, \mathrm{U}$ and $\mathrm{K}$ were acquired by multichannel gamma-ray spectrometer on ground-homogenized 
Tab. 2 continued

\begin{tabular}{|c|c|c|c|c|c|c|c|c|}
\hline Sample & 9 & 10 & 11 & 12 & 13 & 14 & 15 & 16 \\
\hline Type & $\begin{array}{c}\text { YIC } \\
\text { md-cs } \\
\text { Ms-Bt }\end{array}$ & $\begin{array}{c}\text { YIC } \\
\text { md-cs } \\
\text { Ms-Bt }\end{array}$ & $\begin{array}{c}\text { YIC } \\
\text { md-cs } \\
\text { Ms-Bt }\end{array}$ & $\begin{array}{c}\text { YIC } \\
\text { md-cs } \\
\text { Ms-Bt pr }\end{array}$ & $\begin{array}{c}\text { YIC } \\
\text { md pr } \\
\text { Ms-Bt }\end{array}$ & $\begin{array}{c}\text { YIC } \\
\text { md-cs. pr } \\
\text { Ms-Bt }\end{array}$ & $\begin{array}{c}\text { YIC } \\
\text { md-cs } \\
\text { pr Ms-Bt }\end{array}$ & $\begin{array}{c}\text { YIC } \\
\text { md pr } \\
\text { Ms-Bt }\end{array}$ \\
\hline Depth in $\mathrm{m}$ & $572.0-572.5$ & $601.0-601.5$ & $676.0-677.0$ & $787.0-788.0$ & $869.0-869.5$ & $969.0-970.0$ & $1087.0-1088.0$ & $1201.0-1201.5$ \\
\hline $\mathrm{SiO}_{2}$ & 73.85 & 73.45 & 73.47 & 72.62 & 72.74 & 73.07 & 72.53 & 72.83 \\
\hline $\mathrm{TiO}_{2}$ & 0.18 & 0.16 & 0.19 & 0.22 & 0.20 & 0.22 & 0.23 & 0.21 \\
\hline $\mathrm{Al}_{2} \mathrm{O}_{3}$ & 13.83 & 13.83 & 14.01 & 14.54 & 14.38 & 14.19 & 14.39 & 14.32 \\
\hline $\mathrm{Fe}_{2} \mathrm{O}_{3 \text { tot }}$ & 1.37 & 1.17 & 1.30 & 1.41 & 1.48 & 1.41 & 1.65 & 1.46 \\
\hline $\mathrm{MnO}$ & 0.057 & 0.062 & 0.047 & 0.064 & 0.054 & 0.048 & 0.060 & 0.051 \\
\hline $\mathrm{MgO}$ & 0.39 & 0.50 & 0.41 & 0.46 & 0.45 & 0.45 & 0.38 & 0.42 \\
\hline $\mathrm{CaO}$ & 0.61 & 0.55 & 0.64 & 0.72 & 0.68 & 0.64 & 0.71 & 0.75 \\
\hline $\mathrm{Na}_{2} \mathrm{O}$ & 2.77 & 2.00 & 2.72 & 2.53 & 2.35 & 2.58 & 2.75 & 2.87 \\
\hline $\mathrm{K}_{2} \mathrm{O}$ & 4.54 & 4.78 & 4.86 & 4.98 & 5.03 & 4.78 & 4.96 & 5.00 \\
\hline $\mathrm{P}_{2} \mathrm{O}_{5}$ & 0.22 & 0.24 & 0.25 & 0.28 & 0.26 & 0.25 & 0.26 & 0.27 \\
\hline LOD & 0.37 & 0.57 & 0.29 & 0.39 & 0.34 & 0.35 & 0.27 & 0.21 \\
\hline LOI & 1.90 & 2.99 & 1.84 & 1.90 & 1.99 & 2.09 & 1.73 & 1.49 \\
\hline Total & 100.09 & 100.32 & 100.03 & 100.11 & 99.96 & 100.08 & 99.92 & 99.88 \\
\hline As & & & & $<5$ & & & & $<5$ \\
\hline $\mathrm{Cu}$ & & & & $<5$ & & & & $<5$ \\
\hline $\mathrm{Nb}$ & & & & 21 & & & & 18 \\
\hline $\mathrm{Pb}$ & & & & 31 & & & & 36 \\
\hline $\mathrm{Rb}$ & & & & 276 & & & & 259 \\
\hline $\mathrm{Sn}$ & & & & 16 & & & & 15 \\
\hline $\mathrm{Sr}$ & & & & 83 & & & & 81 \\
\hline $\mathrm{V}$ & & & & $<20$ & & & & $<20$ \\
\hline $\mathrm{Y}$ & & & & 29 & & & & 25 \\
\hline $\mathrm{Zn}$ & & & & 44 & & & & 73 \\
\hline $\mathrm{Zr}$ & & & & 125 & & & & 95 \\
\hline
\end{tabular}

samples with a mass of $300 \mathrm{~g}$. The time of measurement was $2000 \mathrm{~s}$.

Sampling intervals were different for individual boreholes and methods used. They ranged from several meters to several tens of meters for petrophysical and reached hundreds of meters for geochemical samples. In figures the sampling interval of petrophysical parameters is for clarity depicted by dots only for the first parameter in one group. For example in Fig. 3 the sampling interval is obvious from the porosity curve (the same interval is for dry bulk density and grain density), magnetic susceptibility (the same interval is for Q-ratio) and gamma-ray activity (identical interval is for the content of radioactive elements $\mathrm{U}$, Th and $\mathrm{K}$ ). In geochemical logs (Figs 4, 6 and 8) each measured sample is depicted by a dot, because the sampling was scarcer in this case.

\subsection{Borehole HJ-1}

Boundary between the OIC and YIC suites at a depth of $460 \mathrm{~m}$ is clearly indicated by an abrupt change in magnetic susceptibility and Th and $\mathrm{U}$ contents (Fig. 3).
Magnetic susceptibility drops from the average value of $88 \times 10^{-6} \mathrm{SI}$ in $\mathrm{OIC}$ to $24 \times 10^{-6} \mathrm{SI}$ in the YIC granites (Tab. 3). The content of Th decreases from $19.1 \mathrm{ppm}$ in the OIC to $8.2 \mathrm{ppm}$ in YIC granites; on the other hand the content of $\mathrm{U}$ increases from $10.1 \mathrm{ppm}$ in the OIC to $16.7 \mathrm{ppm}$ in YIC granites.

Approximately $100 \mathrm{~m}$ thick zone of increased porosity (or a decrease of bulk density) is observed in the OIC granites at the contact with the YIC granites. The contact is also characterized by high values of the Q-ratio, i.e. by an increase of remanent magnetization in comparison with the induced magnetization. This may be caused by reheating of the OIC granites over the Curie temperature of ferromagnetic minerals, by forming of new magnetic minerals during the thermal exchange between the OIC and YIC granites, or by the chemical remanent magnetization originating in minerals formed in cataclastic and altered zone at the boundary of the two granitic intrusions.

The depth changes in the contents of major-element oxides (Fig. 4) correlate with the petrographic type of granites. The silica contents range between 70 and 72 wt. \% in the upper OIC biotite granites with the values typical of the OIC granites (about $70 \mathrm{wt}$ \% silica at 


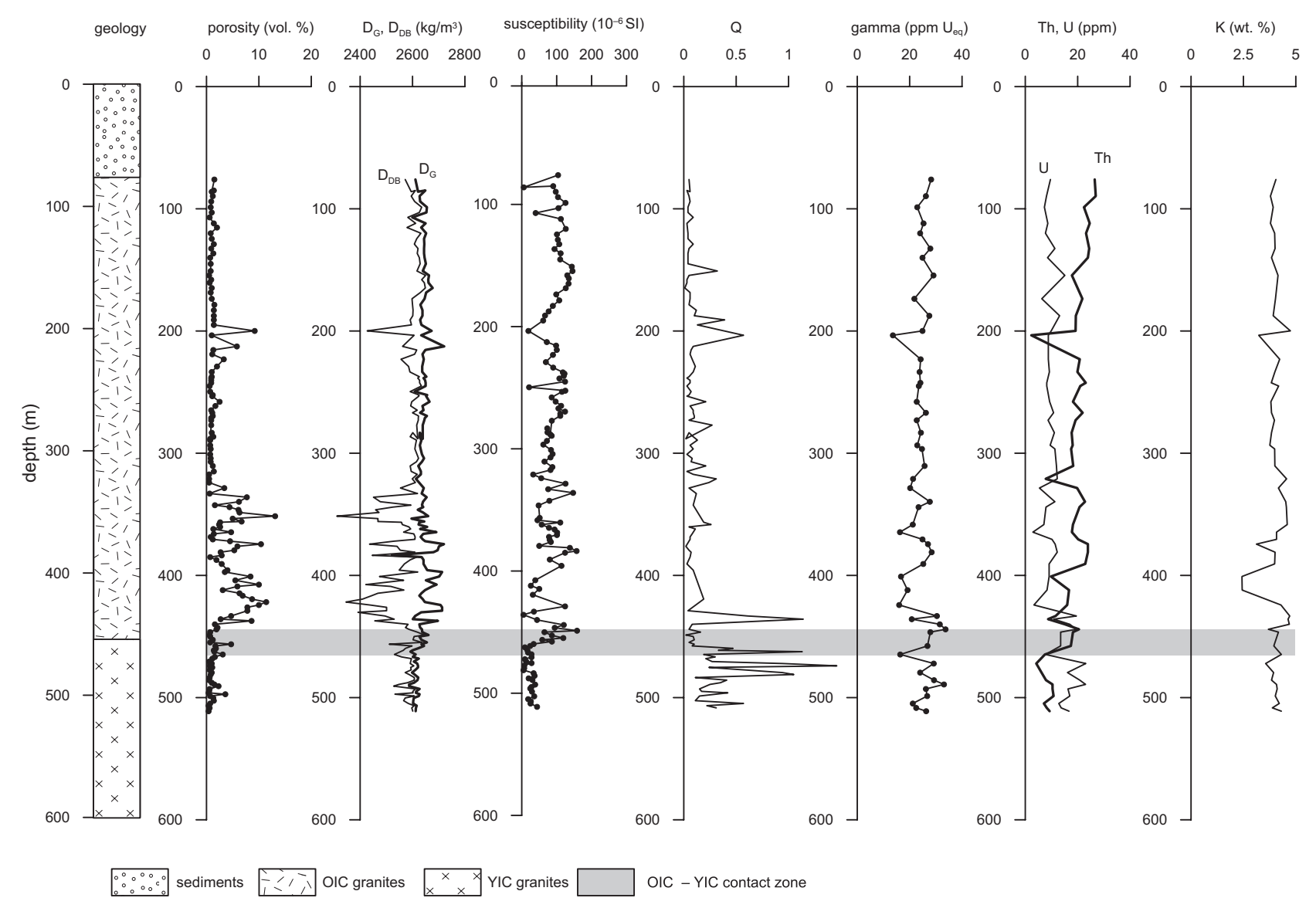

Fig. 3 Petrophysical log of the drill hole HJ-1. $D_{D B}$ - dry bulk density, $D_{G}$ - grain density, Q - Königsberger ratio, gamma - gamma-ray activity.

a depth of $100-150 \mathrm{~m})$ to $c .72 .5$ wt. $\%$ at $\sim 300 \mathrm{~m}$. The value near 73 wt. \% may be caused by silicification (Vylita 1987). However, the steady increase to 75 wt. \% in two-mica granites (at $480 \mathrm{~m}$ ) is caused by the primary silica-rich nature of the YIC granites. $\mathrm{TiO}_{2}$ is relatively constant $(0.29-0.45$ wt. \%) in biotite granites and it drops to $0.07-0.16 \mathrm{wt} \%$ in two-mica granites. The $\mathrm{Fe}_{2} \mathrm{O}_{3 \text { tot }}$ content is only slightly increased in biotite granites $(0.25$ to $0.47 \mathrm{wt}$. \%) relative to two-mica granites $(0.11-0.16$ wt. \%). $\mathrm{MgO}$ displays in biotite granites values between $0.50-1.05$ wt. $\%$ and is significantly lowered to $0.11-0.27$ wt. \% in two-mica granites. $\mathrm{CaO}$ contents are rather variable in biotite granites (1.280.76 wt. \%) and slightly decreased in two-mica granites (0.46- 0.72 wt. \%). The $\mathrm{Na}_{2} \mathrm{O}$ curve shows only small differences between the upper and lower granites. The decrease at $\sim 380 \mathrm{~m}$ is possibly due to sericitization and kaolinization. The leucocratic muscovite granite sample $(480 \mathrm{~m})$ has increased $\mathrm{SiO}_{2}$ and $\mathrm{Na}_{2} \mathrm{O}$ contents and lower amounts of most other oxides and it is exceptional also in petrophysical parameters. No substantial changes were noted between the two petrological suites in $\mathrm{K}_{2} \mathrm{O}$ contents as also indicated by relatively smooth course of $\mathrm{K}$ curve in Fig. 3.

\subsection{Borehole $\mathrm{HJ}-2$}

Granites of the OIC suite begin at a depth of $70 \mathrm{~m}$ below the Tertiary sediments of the Sokolov Basin. Most remarkable physical boundary at $390 \mathrm{~m}$ is characterized by an abrupt change in magnetic susceptibility as well as in Th and U contents (Fig. 5). We correlate this boundary with that observed in the borehole HJ-1 at a depth of $460 \mathrm{~m}$. According to the petrological log, the granites at $262-312 \mathrm{~m}, 317-371 \mathrm{~m}$ and $403-571$ $\mathrm{m}$ are tectonically crushed, altered and silicified. The course of curves of several physical parameters with depth shows that the granites between $390 \mathrm{~m}$ and 560 $\mathrm{m}$ are different from those at greater depths. They have slightly but distinctly lower values of magnetic susceptibilities, contents of Th and $U$, as well as increased values of Q-ratio. We conclude, in accord with other petrological data, that they belong to fractured and altered YIC granites.

The chemical changes with depth are shown in Fig. 6. The curves closely mirror petrographic type of granites and their alterations. Differences in the silica contents between the OIC and YIC granites are distinct. The OIC granites above $390 \mathrm{~m}$ have $\sim 66 \mathrm{wt} \%$ of $\mathrm{SiO}_{2}$, 


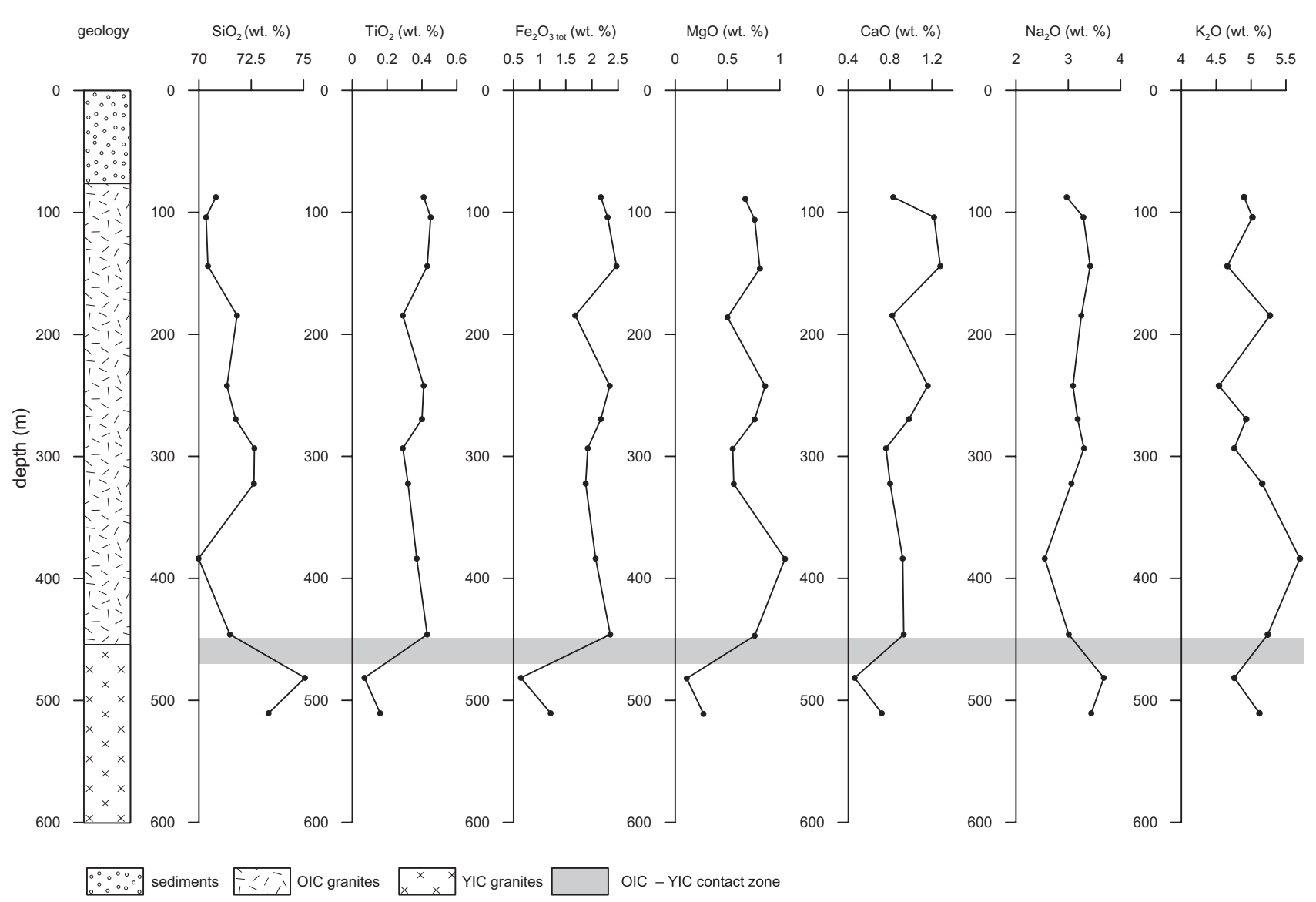

Fig. 4 Geochemical log of the drill hole HJ-1.

i.e. within the range typical of the Loket type (OIC) (Fiala 1968). The sample from $171 \mathrm{~m}$ corresponds to a YIC granite dike, whose $\mathrm{SiO}_{2}$ content is increased to 75 wt. $\%$. The $\mathrm{TiO}_{2}$ contents in the upper OIC granite are c. 0.6 wt. $\%, \mathrm{Fe}_{2} \mathrm{O}_{3 \text { tot }}$ ranges up to 4 wt. $\%$, while $\mathrm{MgO}$ and $\mathrm{CaO}$ vary between 1 and 2 wt. \%. All these values are typical of the Loket type. The lower YIC granites have relatively constant $\mathrm{SiO}_{2}$ contents of $\sim 75$ wt. \%, $\mathrm{TiO}_{2} \sim 0.2$ wt. $\%$ and $\mathrm{CaO} \sim 0.3$ wt. $\%$, i.e. the values characteristic of the YIC granites (Štemprok 1986). The lower amount of biotite in the YIC granites, in contrast to upper biotite granites, is reflected in the lowered contents of $\mathrm{Fe}_{2} \mathrm{O}_{3 \text { tot }}$ (1.2 to 1.5 wt. \%) and $\mathrm{MgO}$ (0.4 to 0.5 wt. $\%$ ). The $\mathrm{K}_{2} \mathrm{O}$ contents in the upper and lower granites are $4-5$ wt. $\%$ and these values are not significantly different between both complexes. The sample from the depth of $495 \mathrm{~m}$ reflects an alteration of plagioclases in the tectonic zone at $390-571 \mathrm{~m}$ by an decrease in $\mathrm{Na}_{2} \mathrm{O}$ to 0.1 wt. $\%$, while the $\mathrm{Na}_{2} \mathrm{O}$ contents for the unaltered granites of both complexes vary between 2 and 3 wt. $\%$. The $\mathrm{SiO}_{2}$ content in this altered zone rises due to silicification, while $\mathrm{Fe}_{2} \mathrm{O}_{3}$ tot drops because of the biotite decomposition. The differences between the OIC and YIC granites (Tab. 2) are also expressed in $\mathrm{Sr}$ contents of 108-297 ppm in the OIC and of 71-83 ppm in YIC granites, $\mathrm{Zr}$ contents of $140-286 \mathrm{ppm}$ in the OIC granites and of 69-125 ppm in the YIC granites. The $\mathrm{Rb}$ values for both complexes overlap within the 157-322 ppm interval, possibly as a consequence of abundant phyllic hydrothermal alterations, which may have obscured the primary differences.

\subsection{Borehole K-25}

The YIC granites are found below $230 \mathrm{~m}$. They were petrographically distinguished by Jarchovský (1994) into albite and leucocratic granites $(230-420 \mathrm{~m})$ with small bodies of fine-grained porphyritic granites, feldspathites $(420-460 \mathrm{~m})$ and Li-mica granites $(460-800 \mathrm{~m})$. The boundary between metamorphic rocks and granites is obvious in magnetic susceptibility, bulk and grain density (Fig. 7). A high porosity zone occurs in granites near the contact with metamorphic rocks. A narrow zone of feldspathites correlates with a zone of low grain density. Limica granites have slightly higher values of gamma-ray activity caused by slightly increased $\mathrm{Th}$ and $\mathrm{U}$ contents.

For testing the nature and extent of alterations in the apical part of the granite, major-element oxides and 


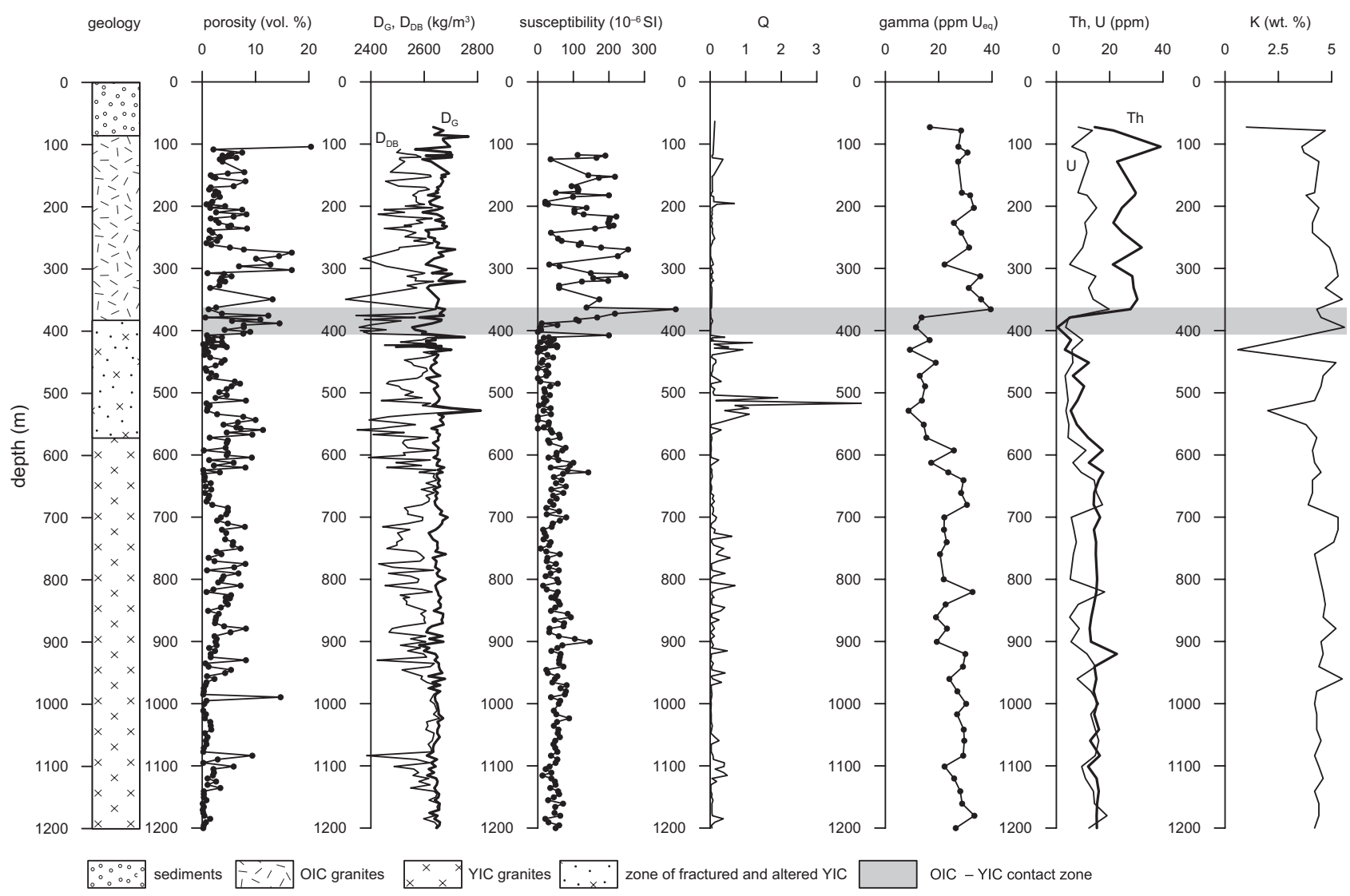

Fig. 5 Petrophysical log of the drill hole HJ-2. $D_{D B}$ - dry bulk density, $D_{G}$ - grain density, $Q$ - Königsberger ratio, gamma - gamma-ray activity.

some trace elements were analysed to follow the decomposition of feldspars and the origin of lithium mica with topaz. The highly variable curves of $\mathrm{Na}_{2} \mathrm{O}, \mathrm{K}_{2} \mathrm{O}, \mathrm{Li}_{2} \mathrm{O}$, F, Rb and Cs (Fig. 8) reflect the extent of greisenization and sericitization in the endocontact of the granites. Greisens are indicated by low $\mathrm{Na}_{2} \mathrm{O}$ and high $\mathrm{Li}_{2} \mathrm{O}$ and $\mathrm{F}$, both the latter curves showing almost an identical course. The curves of $\mathrm{Rb}$ and $\mathrm{Cs}$ are different, reflecting their association with Li-micas in the greisens and granites, as well as with feldspars in the granite. The increased Sn and W contents correlate with the presence of cassiterite and wolframite in greisens immediately below the contact zone. A single increased value of Sn and $\mathrm{W}$ in a depth of $635 \mathrm{~m}$ is possibly connected with a greisenized tectonic zone in Li-mica granite. Metasomatic feldspathites are indicated by lowered $\mathrm{Li}_{2} \mathrm{O}$ and $\mathrm{F}$ contents reflecting the paucity in lithium micas. The peaks of $\mathrm{Rb}$ and $\mathrm{Cs}$ at around $400 \mathrm{~m}$ are difficult to explain from the present data.

\section{Geophysical profile}

Geophysical profile, which crosses boreholes HJ-1 and $\mathrm{HJ}-2$, is $22 \mathrm{~km}$ long. Based on gravity and magnetic data, we compiled a geological cross section to a depth of $\sim 1 \mathrm{~km}$ below the present surface. Besides gravity and magnetic data from the study area, the constraints for constructing the geological cross section were: geological maps of the Czech Republic 1: 500000 (Cháb et al 2007), $1: 200$ 000, Karlovy Vary-Plauen sheet (Zoubek 1996), 1:50 000, Karlovy Vary sheet (Kvičinský 1989) and the Sokolov sheet (Schovánek 1997). Additional data were the depths of geological boundaries, petrophysical properties of the rocks from the boreholes and archive data on densities and magnetic susceptibilities (Blížkovský et al. 1981; Hrouda and Chlupáčová 1993). Position of the geophysical profile in the geological map is in Fig. 2 and the cross section along geophysical profile is in Fig. 9.

We model the OIC granites according to petrophysical data with magnetic susceptibilities of $115 \times 10^{-6} \mathrm{SI}$ and the YIC granites of $35 \times 10^{-6} \mathrm{SI}$, which are average values from boreholes $\mathrm{HJ}-1$ and $\mathrm{HJ}-2$. In gravity modelling, it is a standard procedure to use wet bulk densities of rocks, while in the laboratory the dry bulk densities are normally determined (Tab. 3). Wet bulk densities represent rocks in natural conditions and we calculate them by adding a correction for porosity to the dry bulk densities, assuming $100 \%$ water saturation. Wet bulk 


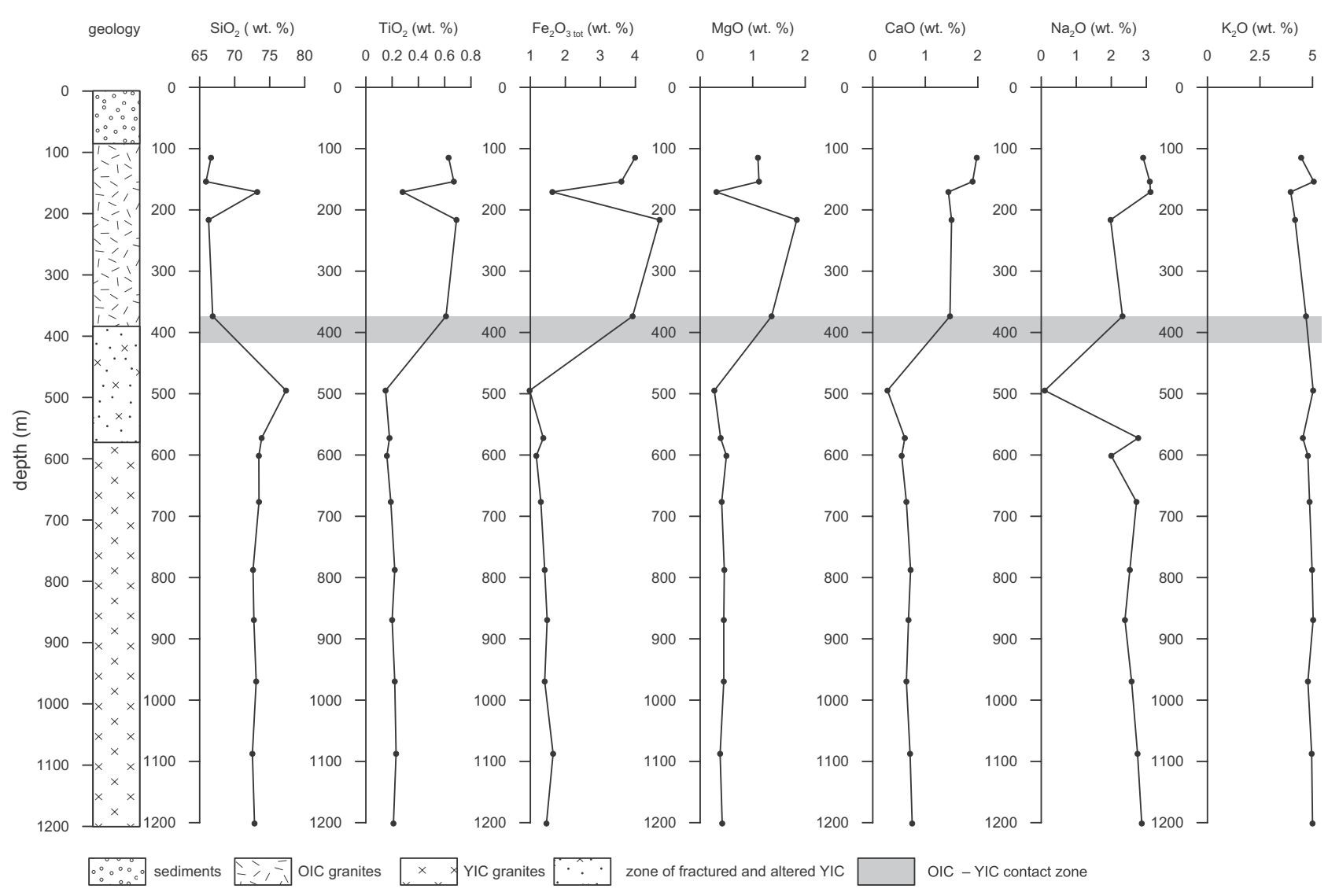

Fig. 6 Geochemical log of the drill hole HJ-2.

densities, calculated as an average for all samples from boreholes HJ-1 and HJ-2, were almost the same for the OIC and YIC granites $-2600 \mathrm{~kg} / \mathrm{m}^{3}$.

In the west, the profile starts in the deepest part of the Tertiary Sokolov Basin. The thickness of sediments reaches almost $400 \mathrm{~m}$ there (Mísař et al. 1983). On the surface, the "Cypris" Formation is represented mainly by claystones and pelocarbonates as well as by brown coal seams. Negative gravity anomaly, with its centre at

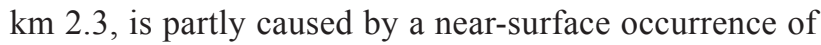
coal seams with a density of $1600 \mathrm{~kg} / \mathrm{m}^{3}$ as evidenced by the open-pit coal mine. Cypris Formation is underlain by Tertiary volcano-detritic formation mainly of sands, clays and tuffs. The crystalline bedrock is in this western part of profile formed by mica schists $\left(2710 \mathrm{~kg} / \mathrm{m}^{3}\right)$. The combined magnetic anomaly (maximum at $\mathrm{km} 1.8$, minimum at $\mathrm{km} \mathrm{4}$ ), is caused by Tertiary volcanic rocks with relatively high magnetic susceptibility $(18000 \times$ $\left.10^{-6} \mathrm{SI}\right)$. We suppose only induced magnetization for this body. Volcanics do not crop out in this part of profile, but from the 1:50 000 geological maps (Kvičinský 1989; Schovánek 1997 and Geological maps of the Czech Republic 2012) it is evident that mafic Tertiary volcanic rocks are frequent in the area of study and pervade both the Tertiary sediments, as well as the Variscan granites.
Magnetic susceptibility of neovolcanics from this region ranges from $7000 \times 10^{-6} \mathrm{SI}$ for phonolite to $103000 \times 10^{-6}$ SI for basalt (Hrouda and Chlupáčová 1993).

In accord with the geological map (Fig. 2), at km 6.3 the profile enters the OIC granites. Between 6.8 and $7.6 \mathrm{~km}$, shallow relics of Oligocene rocks, mainly sandstones and quartzites, overlie the granites. At a depth of $\sim 250 \mathrm{~m}$, we suppose an existence of a tabular body of Tertiary volcanics. Between $\mathrm{km} 8.8$ and 15.8 the profile passes through basal sediments of the Sokolov Basin. The profile is located near its southern margin (Fig. 2) and the thickness of sediments thus reaches some $60 \mathrm{~m}$ only. The exact thickness of sediments was fixed for modelling according to the boundaries recorded in the boreholes HJ-1 and HJ-2. Gravity and magnetic data in this part of the profile imply an occurrence of mafic neovolcanics at depth. A feeding magma channel is probably off the profile line. The YIC granites crop out between $\mathrm{km} 15.8$ and 17.4. In our interpretation, based on the data from the boreholes HJ-1 and HJ-2, the YIC granites form a continuous body at depth. The boundary between the OIC and YIC granites in both boreholes is clearly visible also in curve of magnetic susceptibilities as the former have two to three times higher values than the latter (Fig. 5). But absolute values of magnetic 


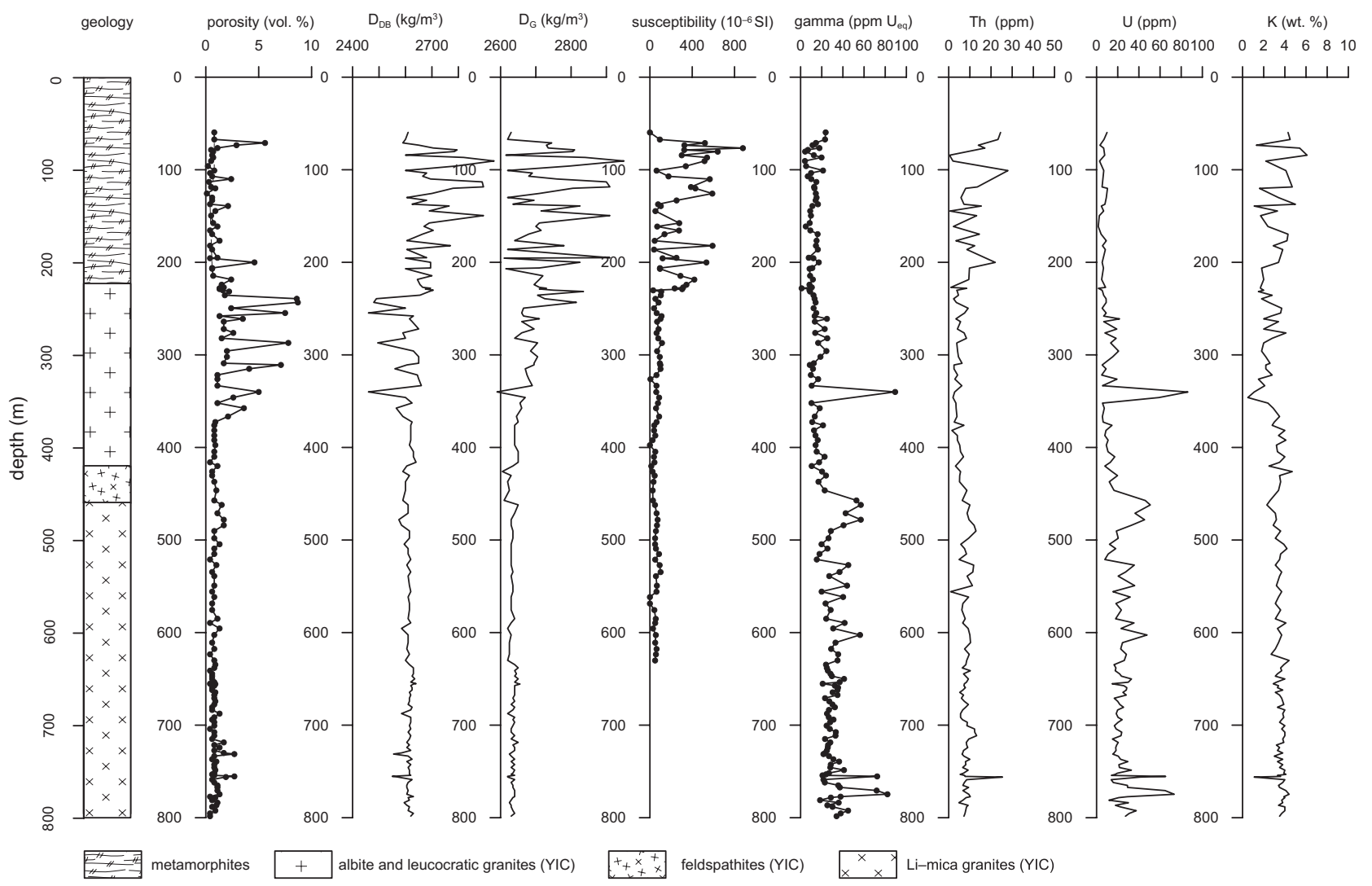

Fig. 7 Petrophysical log of the drill hole K-25. $\mathrm{D}_{\mathrm{DB}}$ - dry bulk density, $\mathrm{D}_{\mathrm{G}}-$ grain density, gamma - gamma-ray activity.

susceptibilities for both the OIC and YIC suites are very low $\left(24-140 \times 10^{-6} \mathrm{SI}\right)$ and the differences between them have negligible influence on the measured and modelled values of the magnetic field.

At $17.4 \mathrm{~km}$, the geophysical profile enters the OIC granites. The values of measured gravity begin to rise as we approach the mafic rocks of the Tertiary Doupov stratovolcano. Volcanics crop out from $\mathrm{km} 20.4$ to the end of the profile. The boundary between the OIC granites and volcanics is marked by a steeply increasing gradient of gravity values and by the most prominent magnetic anomaly on our profile (max. $18.4 \mathrm{~km}$, min. $21.4 \mathrm{~km}$ ). However, the boundary between the granites and volcanics itself does not explain the shape of the magnetic anomaly. To reach an optimal fit between the observed and calculated magnetic data, we had to model a thin tabular intrusion of mafic rocks in granites in the eastern part of the profile. Existence of hidden Tertiary volcanic bodies in area of our study is indicated both by the gravity and magnetic data.

\section{Geochemistry of granitoids}

The Harker diagrams, constructed from the geochemical data of the drill holes and from the set of published or archival data on the granites from the KVM, define linear trends (Fig. 10) suggesting that both the OIC and YIC complexes are parts of a co-magmatic sequence. This is particularly significant in the diagrams of silica vs. $\mathrm{FeO}$, $\mathrm{CaO}$ and $\mathrm{MgO}$. The OIC granites differ from those of the YIC by elevated $\mathrm{TiO}_{2}, \mathrm{FeO}, \mathrm{Fe}_{2} \mathrm{O}_{3 \text { tot, }} \mathrm{CaO}$ and $\mathrm{MgO}$ and lower $\mathrm{SiO}_{2}$ and $\mathrm{Li}$; the granites of the both complexes have similar contents of $\mathrm{P}_{2} \mathrm{O}_{5}$ (Tabs 1-2). The variation diagrams show that the Kfely granites coincide both with the OIC and YIC granites plots, as observed already by Zoubek (1966), and occupy thus an intermediate position between the OIC and YIC granites.

In general, the trace-element geochemistry reported in Štemprok et al. (1996) suggests an increase in incompatible element abundances ( $\mathrm{Li}, \mathrm{W}, \mathrm{Sn}, \mathrm{F}, \mathrm{Cs}$ and $\mathrm{Rb}$ ) with the magma evolution, while the more compatible elements such as $\mathrm{Ba}, \mathrm{Sr}, \mathrm{Co}, \mathrm{Zn}$ and $\mathrm{Pb}$ have higher concentrations in less evolved granitic compositions. The Sn contents range between 7 and $34 \mathrm{ppm}$, and they are substantially lower in the KVM (Tab. 2) than in the mineralized portion of the Western Pluton (Absolonová and Matoulek 1975). In the chondrite-normalized REE diagrams (Štemprok et al. 1996), all the samples are enriched in LREE with variably sized negative Eu anomaly. This is pronounced and comparable with the OIC granites from the Krušné hory/Erzgebirge (lowF biotite granites, e.g., Kirchberg Massif: Eu/*Eu 0.2-0.6) and large for the YIC granites (high-F, high- 


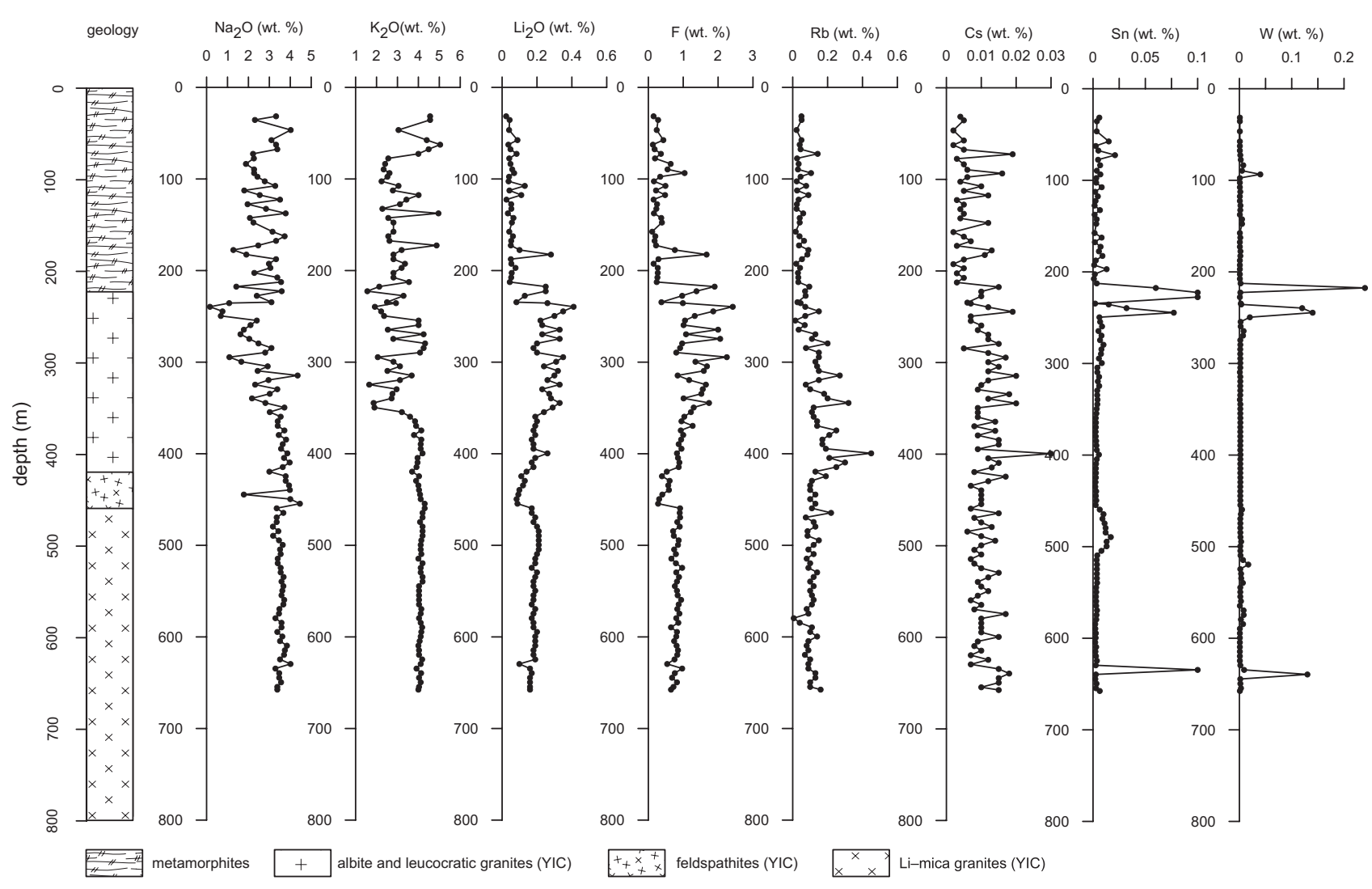

Fig. 8 Geochemical log of the drill hole K-25.

$\mathrm{P}_{2} \mathrm{O}_{5}, \mathrm{Li}$-mica Eibenstock granites: $\mathrm{Eu} /{ }^{*} \mathrm{Eu} \sim 0.05-0.1$ ) (Förster et al. 1999). Majority of samples is peraluminous, in both main intrusive complexes with S-type granite affinities, typical of the YIC granites and mixed S- and I-type character alike the OIC granites (Štemprok 1986; Förster et al. 1999).

\section{Discussion}

The concept of two main granitic suites of distinct composition and age (i.e., the OIC and YIC granites) in the Krušné hory/Erzgebirge Batholith dates back to the second half of the $19^{\text {th }}$ century (e.g. Laube 1876; Fiala 1968; Lange et al.1972; Štemprok 1986). As one of the possible explanations for such chemical differences, Stemprok (1992) suggested a model in which the OIC and YIC granites were generated from the same source, which was in the case of the YIC granites already depleted by the previous extraction of the OIC magmas.

We consider this interpretation acceptable also in light of our new studies. The OIC granites correlate with low-F biotite granites (low-F two-mica), and the YIC granites with high-F, high- $\mathrm{P}_{2} \mathrm{O}_{5}, \mathrm{Li}$-mica granites distinguished in the Erzgebirge by Förster et al. (1999). However, it is important to clarify the position of the so-called "transitional granites" south-east of Karlovy Vary, classified as the Kfely type by Vondrová (1962) and Fiala (1968). These have a chemical composition intermediate between the OIC and YIC granites. We newly assign the "transitional granites" to the YIC and correlate them with the lower granites in the HJ-1 and HJ-2 drillings.

The OIC and YIC granites from the boreholes differ in their average magnetic susceptibility (OIC: $115 \times 10^{-6} \mathrm{SI}$, YIC: $\left.35 \times 10^{-6} \mathrm{SI}\right)$. This is consistent with the measurements on samples collected from outcrops (Blecha and Štemprok 2007). However, different susceptibilities of both complexes are not reflected in the magnetic survey, because the absolute values are very low. Hrouda and Chlupáčová (1993) argued that significant anomalies in the magnetic field may be caused by rocks with susceptibilities higher than approximately $1000 \times 10^{-6}$ SI . Bodies of Tertiary volcanics that pervade granites have such values. Magnetic susceptibilities of west Bohemian neovolcanics vary in a wide range, from phonolites having $7000 \times 10^{-6} \mathrm{SI}$, through trachytes, andesites, nephelinites, foidites to basalts with a susceptibility of $103000 \times 10^{-6}$ SI (Hrouda and Chlupáčová 1993). We model magnetic response of Tertiary neovolcanics with induced magnetization, although the total magnetization depends on the remanent component as well. However, the effect of remanent component in case of continental volcanics rarely prevails. To assume that magnetization is entirely induced is a common practice for magnetic 

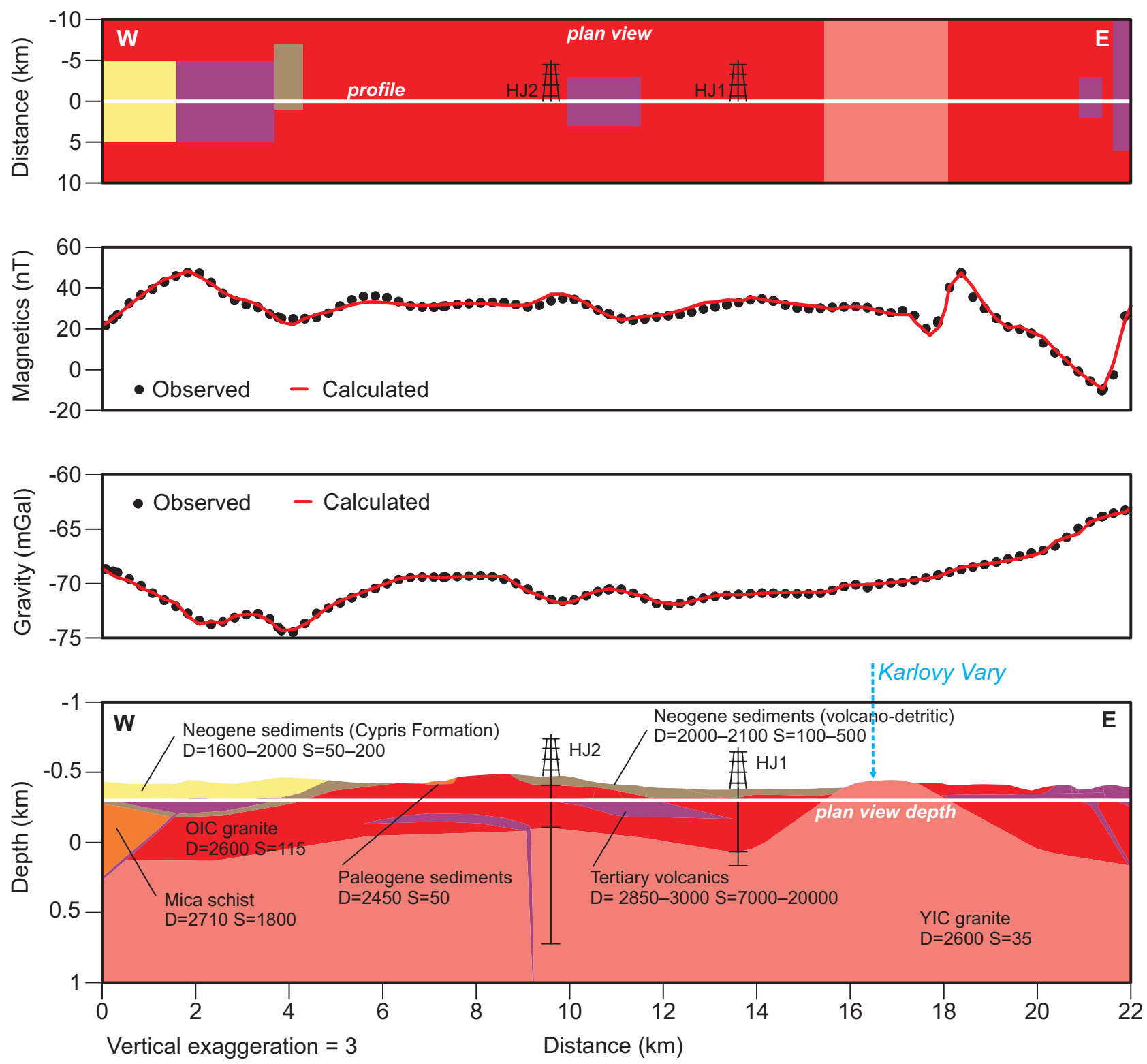

Fig. 9 Geophysical model across the drill holes HJ-1 and HJ-2. Rock densities D are in $\mathrm{kg} / \mathrm{m}^{3}$, magnetic susceptibilities $\mathrm{S}$ are in $\times 10^{-6} \mathrm{SI}$. The upper panel shows the plan view of the model at a depth of $0.3 \mathrm{~km}$ b.s.1.

studies of continental crustal rocks (Lowrie 2007). This makes it easier to design a model to interpret the features responsible for a magnetic anomaly.

Higher magnetic susceptibilities of the OIC granites, compared with the YIC granites, correspond to their less evolved nature and relative enrichment in mafic components, including Fe. Precursors of granitic intrusions in the study area are diorites and gabbrodiorites (redwitzites) with a relatively high content of ferromagnetic accessories and high magnetic susceptibility (Kovář́ková et al. 2007, 2010). The content of magnetic minerals in the subsequent OIC granites is much lower than in diorites and gabbrodiorites. However, according to the values of magnetic susceptibility, it is markedly decreased in the
YIC granites, which are the last member of the magmatic sequence.

The OIC granites have systematically higher contents of Th, which correlate with increased $\mathrm{Zr}$ contents. Higher $\mathrm{Th} / \mathrm{U}$ ratios for OIC granites are obvious from Tab. 3. The usual values of the $\mathrm{Th} / \mathrm{U}$ ratio for acidic and intermediate magmatic rocks range between 3 and 5 (Manová and Matolín 1995; Dickson and Scott 1997), whereas the YIC granites in KVM often show ratios anomalously low, below unity (Blecha and Štemprok 2007). In geophysical prospecting, this fact may be helpful for distinguishing between different granite intrusions by gamma-ray spectrometry on surface outcrops. But due to the extremely small penetration, the radiometric survey does not pro- 
vide any information about the extent of granite intrusions at depth.

The two-mica Kfely granite forms an outcropping body (Fig. 1), which was considered as a separate intrusion in the geological map 1:200 000 (Zoubek 1963). This concept has been later abandoned by Zoubek (1966), because he noted that the chemical composition of these types is close to both fields of the YIC and OIC granites and their compositions overlap in many cases. We accept this view and propose that the bottom parts of the drillings $\mathrm{HJ}-1$ and $\mathrm{HJ}-2$ are formed by the YIC granites. This is supported by the studies of chemical composition of biotites in the $\mathrm{KVM}$, both from mineral separates (Minarík et al. 1984) and by electron microprobe (Štemprok et al. 1996) (Fig. 11). The Fe/ $(\mathrm{Fe}+\mathrm{Mg})$ ratios of biotites from OIC granites and microgranites are c. 0.6-0.7, whereas those of two-mica YIC granites, aplites and transitional two-mica granites (TR in Fig. 11) are more iron-rich and vary predominantly between 0.8 and 0.9 . In our interpretation, both complexes occur as horizontal or subhorizontal sheets where the OIC granites are generally on the top and the YIC granites at the bottom of the known profile. This agrees well with the observation of a sharp flat contact between the OIC and YIC granites in the NEM west of Nejdek in three drill holes (N1, N2 and N3, Klomínský 1965). The OIC granites were identified in the upper and the YIC granites

Fig. 10 Binary plots of $\mathrm{SiO}_{2}$ vs. majorelement oxides and $\mathrm{Li}$ in the granites from the northern part of the KVM. Data are from Neužil and Konta (1965), Fiala (1968), Palivcová et al. (1968), Štochl (1969),Vylita (1987, 1990), Štemprok et al. (1996), Štemprok et al. (2008a), and Lithogeochemical database of the Czech Geological Survey (2010).
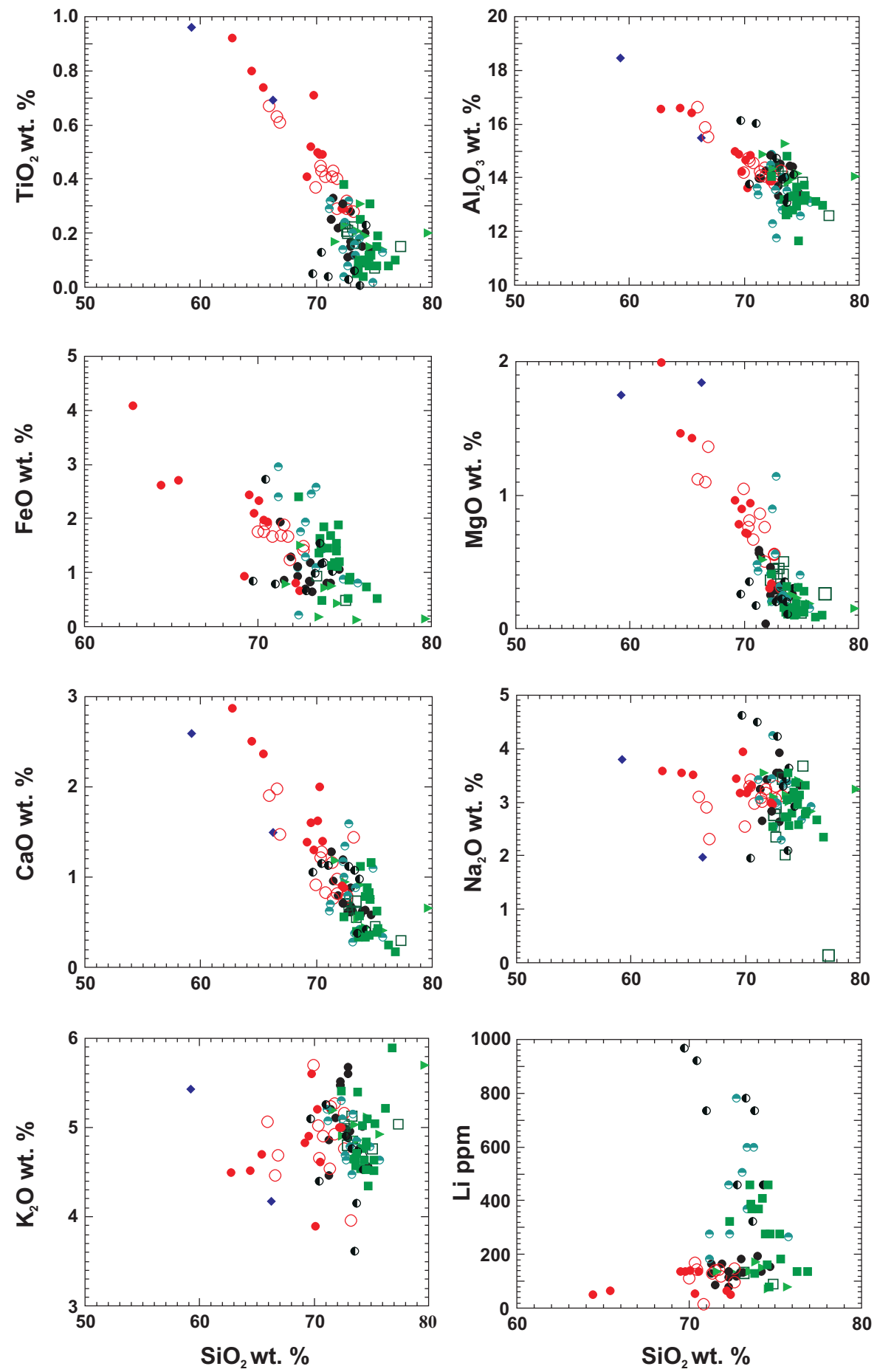

\section{Karlovy Vary Massif}

- diorites

- OIC granites

O OIC granites in drill holes

- YIC microgranites

- YIC granites

- YIC granites (Kfely)

$\square$ YIC granites in drill holes

\section{Krudum Massif}

- YIC two-mica granites (Milíre)

- YIC Li-mica granites (Čistá, Krásno) 
Tab. 3 Average values of selected petrophysical parameters for the granites in drill holes HJ-1, HJ-2 and K-25

\begin{tabular}{|c|c|c|c|c|c|c|c|c|}
\hline borehole & suite & $\begin{array}{c}\mathrm{D}_{\mathrm{DB}} \\
\mathrm{kg} / \mathrm{m}^{3}\end{array}$ & $\begin{array}{c}D_{G} \\
\mathrm{~kg} / \mathrm{m}^{3}\end{array}$ & $\begin{array}{c}\mathrm{S} \\
10^{-6} \mathrm{SI} \\
\end{array}$ & $\begin{array}{c}\text { Th } \\
\text { ppm }\end{array}$ & $\begin{array}{c}\mathrm{U} \\
\mathrm{ppm}\end{array}$ & $\mathrm{Th} / \mathrm{U}$ & $\begin{array}{c}\text { K } \\
\text { wt. \% }\end{array}$ \\
\hline $\mathrm{HJ}-1$ & OIC & 2572 & 2644 & 88 & 19.05 & 10.13 & 2.17 & 3.99 \\
\hline HJ-1 & YIC & 2584 & 2611 & 24 & 8.20 & 16.72 & 0.54 & 4.03 \\
\hline HJ-2 & OIC & 2525 & 2653 & 140 & 25.57 & 11.02 & 2.56 & 4.26 \\
\hline HJ-2 & YIC & 2567 & 2649 & 44 & 13.82 & 10.02 & 1.54 & 4.31 \\
\hline$K-25$ & YIC & 2609 & 2646 & 59 & 7.14 & 21.75 & 0.41 & 3.30 \\
\hline
\end{tabular}

$\mathrm{D}_{\mathrm{DB}}-$ dry bulk density, $\mathrm{D}_{\mathrm{G}}-$ grain density, $\mathrm{S}$ - magnetic susceptibility.

in the lower part of the profile. The YIC was represented by medium-grained muscovite-biotite and fine-grained biotite granites underlain by porphyritic coarse-grained biotite-muscovite types.

Zoubek (1966) applied a concept of tabular intrusion to solve the room problem of the KVM suggesting that granites represent a subhorizontal plate formed by gravitational separation along a subhorizontal discontinuity and subsequent magma intrusion. This explanation is close to interpretation of the shape and internal structure of the Fichtelgebirge/Smrčiny granite Pluton (Hecht et al. 1997). The authors also distinguished here two major intrusive complexes (OIC and YIC) with distinct magma origins, differentiation patterns, shapes of the plutons at depth and zoning patterns with respect to the pluton roots.

Interpretation of the geophysical data shows that the $\mathrm{KVM}$ is, as to the density, a homogenous granite plate interrupted only by Tertiary igneous rocks as indicated in the geophysical profile (Fig. 9). Bodies of diorites,

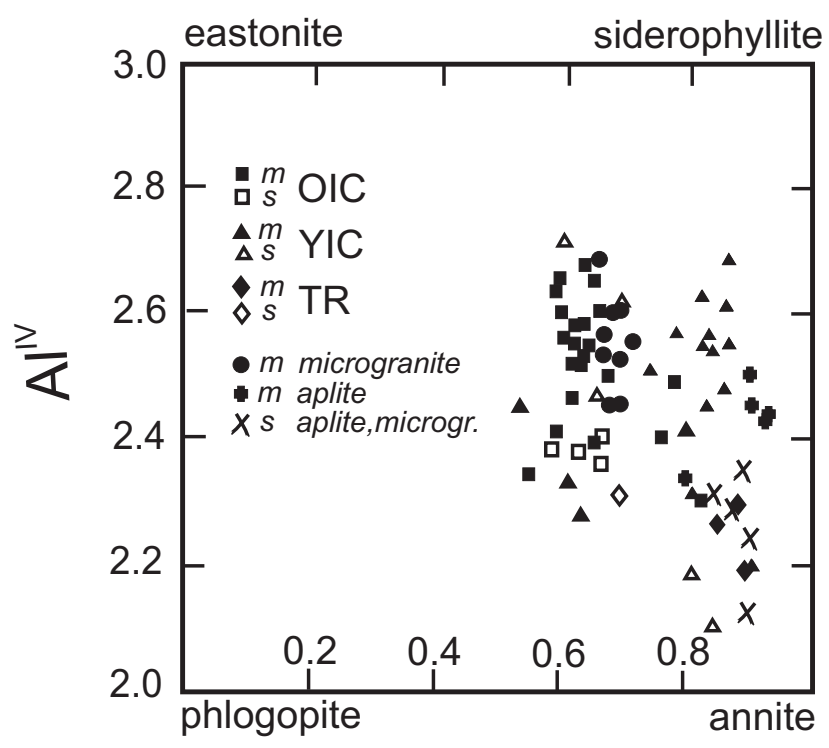

Fig. 11 Composition of biotites from the granites in the profile Karlovy Vary-Březová as compiled from Minařík et al. (1984) (biotite separates $=\mathrm{s}$ ) and from Štemprok et al. (1996) (electron microprobe data = m); $\mathrm{TR}=$ transitional granites sensu Fiala (1968). or the zones of hydrothermal alteration, are of a small size and except of very detailed surveys, they do not disturb the gravity and magnetic fields measured over the granites.

\section{Conclusions}

The Karlovy Vary Massif (KVM) was formed by successive intrusions of the OIC and YIC granites during the Late Paleozoic magmatic activity. Both granites differ in petrophysical parameters (magnetic susceptibility, content of radioactive elements), as well as in composition (mainly $\mathrm{SiO}_{2}, \mathrm{TiO}_{2}, \mathrm{FeO}, \mathrm{Fe}_{2} \mathrm{O}_{3 \text { tot }}, \mathrm{MgO}$, $\mathrm{CaO}$, and $\mathrm{Li}$ contents). We interpret the vertical structure of the Massif as a tabular intrusion of earlier OIC biotite granites underlain by a subhorizontal plate of the two-mica YIC granites, which crop out in four separate bodies (Karlovy Vary, Kfely, Krudum and Lesný-Lysina massifs). The KVM is penetrated by Tertiary volcanics, partly hidden in the Massif. Densities of the OIC and YIC granites are almost identical, whereas the magnetic susceptibilities of the OIC granites are markedly higher than those of the YIC granites. However, the absolute values of the magnetic susceptibility for both granitic complexes are very low and cannot thus significantly affect the geomagnetic field. This means that the gravity and magnetic surveys cannot distinguish granitic intrusions of different compositions and times of emplacement.

Our data on the petrophysical properties of granites are from depths of $c .1 \mathrm{~km}$ and previous geophysical studies indicate that the thickness of the KVM is approximately $10 \mathrm{~km}$. With respect to the temperature and pressure that we expect at that depth and the low porosity of granites, as well as a minor influence of deeper parts of granites on values of the magnetic field measured on the ground, we assume that our results may be applied to the whole KVM. We therefore conclude that the lack of knowledge on spatial distribution of individual granitic intrusions at depth does not affect the accuracy of geological interpretations of gravity and magnetic data over the entire granitic body. 
Acknowledgements. The authors gratefully acknowledge the support of the Ministry of Education, Youth and Sports of the Czech Republic (project MSM 0021620855). We are grateful to Jiř́ Sedlák and an anonymous reviewer for critical comments. We appreciate helpful handling of the manuscript by V. Babuška and careful reading of the manuscript by the chief editor Vojtěch Janoušek and his valuable improvements of the content, style and English language.

\section{References}

Absolonová E, Matoulek M (1975) Geochemical distribution of elements in the Karlovy Vary Massif. Sbor geol Věd, ložisk Geol Mineral 17: 7-32 (in Czech)

BabušKa V, Plomerová J (2001) Subcrustal lithosphere around the Saxothuringian-Moldanubian suture zone - a model derived from anisotropy of the seismic wave velocities. Tectonophysics 332: 185-199

BABUŠKa V, Plomerová J (2010) Mantle lithosphere control of crustal tectonics and magmatism of the western Ohře (Eger) Rift. J Geosci 55: 171-186

Babuška V, Plomerová J, Fischer T (2007) Intraplate seismicity in the western Bohemian Massif (central Europe): a possible correlation with a paleoplate junction. J Geodyn 44: 149-159

Blecha V, ŠTemprok M (2007) Physical properties of granites from the Variscan Karlovy Vary (Carlsbad) Massif (Czech Republic). Extended Abstracts of $69^{\text {th }}$ EAGE Conference, London, E024: 1-5

Blecha V, ŠTemprok M, Fischer T (2009) Geological interpretation of gravity profiles through the Karlovy Vary granite Massif (Czech Republic). Stud Geophys Geod 53: 295-314

Blížkovský M, Čejchanová B, Friáková O, Hanák J, Kadlec E, Mitrenga P, Novák M, Novotný A, Ondra P, ŠvancARA J (1981) Construction of the stripped gravity map of the Bohemian Massif based on the revision of density data. Part II Density data from the Bohemian Massif on the territory of Czechoslovakia. Unpublished manuscript, Czech Geological Survey - Geofond, Prague, pp 1-323 (in Czech)

Breiter K, Sokolová M, Sokol A (1991) Geochemical specialization of the tin-bearing granitoid massifs of $\mathrm{NW}$ Bohemia. Miner Depos 26: 298-306

CHÁB J, Stráník Z Eliáš M (2007) Geological map of the Czech Republic at scale 1: 500 000, Czech Geological Survey, Prague

Clemens JD, Helps PA, Stevens G (2010) Chemical structure in granitic magmas - a signal from the source. Earth Environ Sci Trans R Soc Edinb 100: 15-172

Cruden AR (2006) Emplacement and growth of plutons: implications of rates of melting and mass transfer in continental crust. In: Brown M, RusHMER T (eds) Evolution and Differentiation of the Continental Crust. Cambridge University Press, pp 455-519

Čápová D, Chlupáčová M, Gnojek I, Hanák J, Hladík V, Hrouda F, HudečKová E, Kašparec I, Kolejka V, Matěj F, Ondra P, RŮŽıčKová M, Sedlák J, ŠRÁmek J, ZABADAL S (2004) Organization and use of geophysical data acquired by the state budget, stage 2004. Unpublished manuscript, Czech Geological Survey - Geofond, Prague, pp 1-123 (in Czech)

Dickson BL, ScotT KM (1997) Interpretation of aerial gamma ray surveys - adding the geochemical factors. BMR J Aust Geol Geoph 17: 187-200

DolAnskÁ M (1989) Multipurpose structural borehole HJ-2 Karlovy Vary. Laboratory determination of physical properties of rocks on the drill samples. Unpublished manuscript, Czech Geological Survey - Geofond, Prague, pp 1-14 (in Czech)

Fiala F (1968) Granitoids of the Slavkovský (Císařský) les Mountains. Sbor geol Věd, Geol 14: 93-145

Förster H-J, Romer RL (2010) Carboniferous magmatism. In: Linnemann U, Romer RL (eds) Pre-Mesozoic Geology of Saxo-Thuringia - From the Cadomian Active Margin to the Variscan Orogen. Schweizerbart, Stuttgart, pp 287-308

Förster H-J, Tischendorf G, Trumbull RB, Gottesmann B (1999) Late collisional granites of the Variscan Erzgebirge, Germany. J Petrol 40: 1615-1645

FRANKE W (1989) Tectonostratigraphic units in the Variscan belt of Central Europe. In: DALLMEYER RD (ed) Terranes in Circum-Atlantic Paleozoic orogens. Geological Society of America Special Papers 230: 67-90

Geological maps of the Czech Republic on-line. Accessed on January 18, 2012, at http://www.geologicke-mapy.cz/ regiony/

GM-SYS Modelling (2012) Accessed on January 18, 2012, at http://www.geosoft.com/products/gm-sys

Hecht L, Vigneresse JL, Morteani G (1997) Constraints on the origin of zonation of the granite complexes in the Fichtelgebirge (Germany and Czech Republic): evidence from a gravity and geochemical study. Geol Rundsch 86: S93-S109

Hejtman B (1984) Petrography of Igneous Rocks of the Bohemian Massif, Part 1, Intrusive Igneous Rocks of the Western and North-western Bohemia. Charles University, Prague, pp 1-185 (in Czech)

HroudA F, CHLupÁČOvÁ M (1993) A petrophysical study, part II: densities, magnetic properties, elasticity and radioactivity. In: VRÁNA S, ŠTĚDRÁ V (eds) Geological model of Western Bohemia in relation to the deep borehole (KTB1) in FRG. Unpublished manuscript, Czech Geological Survey - Geofond, Prague, pp 1-110 (in Czech)

Ibrmajer J, Suk M (eds) (1989) Geophysical Image of the ČSSR. Czech Geological Survey, Prague, pp 1-354 (in Czech) 
JARCHOVSKÝ T (1994) Inner structure of tin-tungsten bearing cupolas near Krásno (Slavkovský les Mts.). In: SELTMANN R, KÄMPF H, MöLler P (eds) Metallogeny of Collisional Orogens. Czech Geological Survey, Prague, pp 137-141

JARCHOVSKÝ T (2006) The nature and genesis of greisen stocks at Krásno, Slavkovský les area - Western Bohemia, Czech Republic. J Czech Geol Soc 51: 201-216

JELÍNEK E, ŠTĚDRÁ V, CHÁB J (1997) The Marianské Lázně Complex. In: VRÁNA S, ŠTĚDRÁ V (eds) Geological model of Western Bohemia Related to the KTB Borehole in Germany. Sbor geol Věd, Geol 47: 61-70

KLOMínskÝ J (1965) Der Kontakt des "Gebirgs" und "Erzgebirgsgranit” im Massiv von Karlovy Vary bei Nejdek in Krušné hory. Věst Ústř úst geol 40: 197-198

KodymovÁ A, ŠTemprok M (1993) Typology and internal structure of zircons from the granites of the Krušné hory-Erzgebirge Batholith and associated rhyolite and granite porphyry (Czech Republic). J Czech Geol Soc 38: 149-163

KováŘíková P, Siebel W, Jelínek E, Štemprok M, Kachlík V, Holub FV, Blecha V (2007) Petrology, geochemistry and zircon age of redwitzite at Abertamy, NW Bohemian Massif (Czech Republic): tracing the mantle component in Late Variscan intrusions. Chem Erde 67: 151-174

KováŘíková P, Siebel W, JelíneK E, ŠTemprok M, Kachlík V, Holub FV, Blecha V (2010) Dioritic intrusions of the Slavkovský les (Kaiserwald), Western Bohemia: their origin and significance in late Variscan granitoid magmatism. Int J Earth Sci 99: 545-565

KVIČINSKÝ Z (ed) (1989) Geological map of the Czech Republic 1:50 000, sheet 11-21 Karlovy Vary. Czech Geological Survey, Prague

Lange H, Tischendorf G, Pälchen W, Klemm I, Ossenkopf W (1972) Zur Petrographie und Geochemie der Granite des Erzgebirges. Geologie 21: 457-492

Laube GC (1876) Geologie des Böhmischen Erzgebirges. Part I, Verlag F. Řivnáč, Prague, pp 1-208

Lithogeochemical database of the Czech Geological SuRVEY (2010) Database online. Accessed on November 14, 2011, at http://www.geology.cz/litogeochemie

LOWRIE W (2007) Fundamentals of Geophysics. Cambridge University Press, pp 1-381

Manová M, Matolín M (1995) Radiometric map of the Czech Republic 1 : 500 000. Czech Geological Survey, Prague, pp 1-19

Minařík L, Houdková Z, Absolon K, Köllnerová Z (1984) Geochemistry of biotites from the Karlovy Vary granite Massif. Acta Montana 68: 33-44 (in Czech)

Mísař Z, Dudek A, Havlena V, Weiss J (1983) Geology of ČSSR I, Bohemian Massif. SPN Prague, pp 1-333 (in Czech)

NeužIl J, Konta J (1965) Petrology and geochemistry of the Karlovy Vary granite, the parent rock of the Sedlec kaolin. Acta Univ Carol, Geol, Suppl 2: 41-56

Palivcová M, Beneš K, ZoubeK V (1968) Genesis of Granitoids in the Bohemian Massif. Guide to Excursion 29 AC, International Geological Congress, 23 ${ }^{\text {rd }}$ session. Czech Geological Survey, Prague, pp 1-42

Pivec E (1973) X-ray, optical and chemical variation of potash feldspar from Loket (Elbogen), Karlovy Vary Massif, Czechoslovakia. Tschermaks Min Petr Mitt 19: 87-94

SCHOVÁNEK P (ed) (1997) Geological map of the Czech Republic 1:50 000, sheet 11-23 Sokolov. Czech Geological Survey, Prague

Sedlák J, Gnojek I, Scheibe R, Zabadal S (2009) Gravity response of igneous rocks in the northwestern part of the Bohemian Massif. J Geosci 54: 325-342

ŠKVOR V (1986) The granite pluton of the Krušné hory and its interpretation. Věst Ústř úst geol 61: 67-71 (in Czech)

ŠTeMProK M (1986) Petrology and geochemistry of the Czechoslovak part of the Krušné hory Mts. granite Pluton. Sbor geol Věd, ložisk Geol Mineral 27: 111-156

ŠTEMPROK M (1992) Geochemical development of the Krušné hory/Erzgebirge granite Pluton exemplified on its Czechoslovak part. Geophys Veröff Univ Leipzig 4: 51-63

Štemprok M, Zoubek V, Pivec E, Lang M (1996) Karlovy Vary Pluton: an example of comagmatic sequence of Sn-bearing body. Freiberg Forsch H C467: 7-26

ŠTemprok M, Dolejš D, Müller A, Seltmann R (2008a) Textural evidence of magma decompression, devolatilisation and disequilibrium quenching: an example from the Western Krušné hory/Erzgebirge Pluton. Contrib Mineral Petrol 155: 93-109

Štemprok M, Seifert T, Holub FV, Chlupáčová M, Dolejš D, Novák JK, Pivec E, Lang M (2008b) Petrology and geochemistry of Variscan dykes from the Jáchymov (Joachimsthal) ore district, Czech Republic. J Geosci 53: $65-104$

ŠTochl V (1969) Geochemistry of gases in inclusions of granites of the Karlovy Vary granite Massif and their determination by gas chromatography. Unpublished CSc. (Ph.D.) thesis. Geological Institute of the Czechoslovak Academy of Science, pp 1-168 (in Czech)

Trzebski R, Behr HJ, Conrad W (1997) Subsurface distribution and tectonic setting of the late-Variscan granites in the northwestern Bohemian Massif. Geol Rundsch 86: S64-S78

VANĚČKOVÁ M (1988) Multipurpose structural borehole Karlovy Vary. Laboratory determination of physical properties of rocks on the drill samples. Unpublished manuscript, Czech Geological Survey - Geofond, Prague, pp 1-16 (in Czech)

Vigneresse JL (2007) The role of discontinuous magma inputs in felsic magmas and ore generation. Ore Geol Rev 30: 181-216 
VONDROVÁ N (1962) Final report on the geological study in the north-eastern part of the Slavkovský les. Unpublished manuscript, Czech Geological Survey - Geofond, Prague, pp 1-173 (in Czech)

Vylita B (1987) Report of hydrogeological research in Karlovy Vary - structural drilling. Stavební geologie, n. p. Unpublished manuscript, Czech Geological Survey - Geofond, Prague, pp 1-52 (in Czech)

Vylita B (1990) Karlovy Vary - Structural drilling HJ-2. Stavební geologie, n.p. Unpublished manuscript, Czech Geological Survey - Geofond, Prague, pp 1-111 (in Czech)

Vylita B, Bodlák P, DomečKa K, PĚČek J, Zeman J (1991) New knowledge about the Karlovy Vary spring structure. Knihovna ÚUUG 63: 1-107 (in Czech)
Zoubek V (1951) Preliminary report on the geological research in the area of Karlovy Vary pluton. Věst Ústř úst geol 26: 166-179 (in Czech)

ZoubeK V (ed) (1963) Explanatory notes to the general geological map $1: 200$ 000, sheet M-33-XIII Karlovy Vary. Czech Geological Survey, Prague, pp 1-290 (in Czech)

ZoubeK V (1966) Karlovy Vary granite Massif: profile Karlovy Vary Březová dam. Zpr geol výzk v r 1965, Czech Geological Survey, Prague, pp 50-52 (in Czech)

ZoubeK V (ed) (1996) Geological map of the Czech Republic 1:200 000, sheet M-33-XIII Karlovy Vary-Plauen. Czech Geological Survey, Prague 